\title{
Fluid Chemistry of Mid-Ocean Ridge Hydrothermal Vents: A Comparison between Numerical Modeling and Vent Geochemical Data
}

\author{
Samuel Pierre $\mathbb{D}^{D}$, Alexander P. Gysi $\mathbb{D}^{D}$, and Thomas Monecke \\ Center for Mineral Resources Science, Department of Geology and Geological Engineering, Colorado School of Mines, \\ 1516 Illinois Street, Golden, CO 80401, USA
}

Correspondence should be addressed to Samuel Pierre; spierre@mines.edu

Received 23 February 2018; Revised 18 August 2018; Accepted 12 September 2018; Published 31 October 2018

Academic Editor: Stefano Lo Russo

Copyright (c) 2018 Samuel Pierre et al. This is an open access article distributed under the Creative Commons Attribution License, which permits unrestricted use, distribution, and reproduction in any medium, provided the original work is properly cited.

\begin{abstract}
Seawater-basalt interaction taking place at mid-ocean ridges was studied using numerical modeling to determine the compositional evolution of hydrothermal fluids and associated alteration mineralogy forming within newly emplaced crustal material. Geochemical modeling was carried out in a closed seawater-basalt system at discrete temperature intervals between 2 and $400^{\circ} \mathrm{C}$ at 500 bars, varying fluid/rock ratios, and secondary mineral assemblages representative of basalt alteration in natural systems. In addition to temperature, the fluid/rock ratio has a fundamental control on the resulting system chemistry. At rock-buffered conditions (low fluid/rock ratios), the mineral-solution equilibrium was characterized by high cation to proton activity ratios for $a \mathrm{Ca}^{2+} /\left(a \mathrm{H}^{+}\right)^{2}$ and $a \mathrm{Na}^{+} / a \mathrm{H}^{+}$and very low dissolved $\mathrm{Mg}$ concentrations due to the precipitation of smectites and chlorite. A complex secondary mineral alteration assemblage dominated by $\mathrm{Ca}$ - and $\mathrm{Na}$-bearing minerals including zeolites, calcite, epidote, prehnite, clinozoisite, and albite was predicted to form. The resulting fluid composition was alkaline and reduced relative to ambient seawater, with Eh values ranging between -0.2 and $-0.6 \mathrm{~V}$. In contrast, seawater-buffered conditions (high fluid/ rock ratios) resulted in lower cation to proton activity ratios for $a \mathrm{Ca}^{2+} /\left(a \mathrm{H}^{+}\right)^{2}$ and $a \mathrm{Na}^{+} / a \mathrm{H}^{+}$and higher dissolved $\mathrm{Mg}$ concentrations comparable to the value of this element in ambient seawater. A more simple mineral assemblage was predicted to form at these conditions with the predominance of $\mathrm{Al}$-Si- and $\mathrm{Mg}$-bearing minerals including kaolinite, quartz, and talc in addition to large amounts of anhydrite. The resulting fluid composition was mildly acidic and oxidized relative to seawater with Eh values ranging between -0.2 and $0 \mathrm{~V}$. These modeling results were compared to a compilation of submarine hydrothermal vent fluid compositions from mid-ocean ridge settings and analogous basalt-dominated environments. The agreement obtained between the simulations and the compiled fluid data indicates that mid-ocean ridge hydrothermal processes can be closely reproduced by mineral-solution equilibria for a broad range of temperatures and fluid/rock ratios.
\end{abstract}

\section{Introduction}

Mid-ocean ridges account for more than 60 percent of the Earth's global magmatic budget [1] and generate a hydrothermal energy output of $1.8 \pm 0.3$ TW [2] via both low- $\left(<200^{\circ} \mathrm{C}\right)$ and high- $\left(>200^{\circ} \mathrm{C}\right)$ temperature fluid fluxes. Since the first discoveries of active high-temperature hydrothermal vents in the late 1970s [3, 4], it has been recognized that seawater circulation within the oceanic crust represents one of the principal mechanisms of heat transfer. During circulation, seawater is heated to a maximum temperature of $\sim 400^{\circ} \mathrm{C}[5,6]$ and is chemically modified due to interaction with rocks along the fluid flow pathways $[7,8]$. Because the permeability of the oceanic crust varies with depth and from one vent field to another, various regimes of seawater circulation are expected to occur, affecting the chemistry of the hydrothermal fluids $[9,10]$. In particular, the fluid/ rock $(F / R)$ ratio has a pronounced effect on the composition of both the fluids and alteration mineralogy produced during fluid/rock interaction $[11,12]$. 
In a pioneering work, Bowers and Taylor [13] simulated the evolution of hydrothermal fluids at the $21^{\circ} \mathrm{N}$ East Pacific Rise vent field at temperatures between 100 and $350^{\circ} \mathrm{C}$ and an average F/R ratio of 0.5. Berndt et al. [14] and Seyfried et al. [15] showed that temperature-dependent fluid/rock equilibria between dissolved $\mathrm{Ca}, \mathrm{Na}$, and $\mathrm{Si}$ and their corresponding mineral buffers could explain the variation of these elements in mid-ocean ridge hydrothermal fluids. Wetzel and Shock [16] extended this observation to a broader fluid-mineral compositional range at temperatures between 350 and $400^{\circ} \mathrm{C}$ and an $\mathrm{F} / \mathrm{R}$ ratio of 1 . Although realistic hydrothermal fluid compositions were obtained in these studies, the applicability of thermodynamic modeling was limited by the choice of a fixed F/R ratio. Bowers and Taylor [13] and Bowers et al. [17] determined that the overall $\mathrm{F} / \mathrm{R}$ ratio from the $21^{\circ} \mathrm{N}$ East Pacific Rise vent field is 0.5 based on a $\delta^{18} \mathrm{O}_{\mathrm{H} 2 \mathrm{O}}$ value of $+2.0 \%$ in a $350^{\circ} \mathrm{C}$ hydrothermal fluid. However, more recent vent data have reported isotopic values ranging from 0 to $+2.5 \%$ o [18-20], suggesting that the $F / R$ ratio in mid-ocean ridge hydrothermal systems can vary significantly. Fluid/rock ratios have been estimated to range from $\sim 1$ to $\sim 100$ based on various methods including boron isotopic and energy balance calculations [2, 9, 21-24].

To better understand the processes of fluid/rock interaction taking place during seawater circulation through the oceanic crust, the present contribution examines the factors controlling the chemistry of hydrothermal fluids generated at mid-ocean ridges. Numerical modeling was conducted using the GEMS code package [25-28] based on the Gibbs energy minimization (GEM) method to constrain the influence of the rock composition, F/R ratio, and temperature on the fluid composition and corresponding alteration mineralogy formed during seawater circulation in the oceanic crust. Modeling results are compared to the fluid and mineral chemistry of basalt-dominated subaerial and submarine hydrothermal systems to demonstrate the validity of the simulations. The agreement between modeling results and the composition of natural waters indicates that midocean ridge hydrothermal systems share similar patterns of fluid evolution, which can now be effectively modeled using the GEM method.

\section{Methods}

2.1. Geochemical Modeling. Numerical simulations were conducted in the Na-K-Mg-Ca-Ti-Fe-Al-C-Si-S-F-Cl-H-O system using the GEM-Selektor v.3 code package (http:// gems.web.psi.ch). This program evaluates chemical equilibria among fluid and minerals using the GEM method, which provides advantages for the calculation of $\mathrm{pH}$ and redox in complex hydrothermal fluids in comparison to the more conventionally used law of mass action (LMA) type codes [25-28]. Thermodynamic data used for the minerals and aqueous species were obtained from the MINES 17 database (http://tdb.mines.edu) [29]. Data for rock-forming minerals were taken from Holland and Powell [30] and Gysi and Stefánsson [31], and data for aqueous species were taken from Supcrt92 [32-34]. This dataset was updated with experimental data for the dissociation constant of $\mathrm{HCl}[35]$ and the internally consistent dataset of Miron et al. [36] for Na-K-Al$\mathrm{Si}$ obtained using the GEMSFITS code package [37], extended to $\mathrm{Ca}-\mathrm{Mg}-\mathrm{CO}_{2}$ by Miron et al. [38]. A list of minerals included in the simulations is given in Figure 1.

The standard state adopted for minerals was that of the pure phase at any temperature and pressure. An ideal solid solution model was used for sheet silicates and zeolites, and the estimated thermodynamic properties for their endmembers can be found in Gysi and Stefánsson [31] and Gysi [29]. The standard state adopted for pure $\mathrm{H}_{2} \mathrm{O}$ and for the aqueous species was unit activity in a hypothetical one molal standard solution referenced at infinite dilution at any pressure and temperature. The extended Debye-Hückel activity model was used for aqueous species assuming $\mathrm{NaCl}$ as the background electrolyte [52, 53]. All activity models and equations of state were calculated using the TSolMod library class implemented in GEM-Selektor [54].

2.2. Geological Parameters and Simulation Setup. Seawaterrock interaction was simulated under closed-system conditions using a titration model for temperatures ranging from 2 to $400^{\circ} \mathrm{C}$ in steps of $2^{\circ} \mathrm{C}$, a constant pressure of 500 bars, and $\mathrm{F} / \mathrm{R}$ ratios ranging from 1 to 100 . The fluid/rock equilibrium was calculated at each temperature step to monitor the dissolution of primary minerals, precipitation-dissolution of secondary minerals, and associated changes in the composition of seawater. The model is aimed at approximating the circulation and equilibration of fresh seawater in a young mid-ocean ridge crust, where seawater reacts with unaltered basalts along a prograde temperature path covering a vertical section from the seafloor to the top of the subaxial magma chamber. The calculations were repeated for different $\mathrm{F} / \mathrm{R}$ ratios (i.e., one section per $\mathrm{F} / \mathrm{R}$ ratio), assuming that the value of the $\mathrm{F} / \mathrm{R}$ ratio represents the overall fluid/rock equilibria attained in a section. The $\mathrm{F} / \mathrm{R}$ ratio can be related to the natural circulation of fluids within a given volume of rock that yields a given amount of mineral surfaces accessible for reaction. Natural open systems involve complex dynamic fluid flow in time and space, largely due to variations in rock porosity and permeability between various rock units and depending on fracture networks and faulting. The $\mathrm{F} / \mathrm{R}$ ratio is a concept that can be seen as the effective result of fluid/rock interaction in the open hydrothermal system, where local chemical equilibrium has been achieved.

The compositions of mid-ocean ridge basalt and seawater used in the numerical model are listed in Table 1. The basalt composition was calculated by averaging the major element composition of eight fresh basaltic glasses and their reported $\mathrm{Fe}^{3+} / \sum \mathrm{Fe}$ ratios (data from Kelley and Cottrell [55]), which is an important parameter to fix the initial redox potential of the system. Major element analyses of the basaltic glasses were normalized to $100 \mathrm{wt} . \%$, without taking into account the low concentrations in $\mathrm{MnO}$ and $\mathrm{P}_{2} \mathrm{O}_{5}$. The composition of seawater was taken from the reference composition of Millero et al. [56] and normalized to the components of the system. The minor concentration of $\mathrm{Sr}^{2+}$ in seawater was converted to $\mathrm{Ca}^{2+}$ to maintain charge balance. Similarly, $\mathrm{Br}^{-}$was converted to $\mathrm{Cl}^{-}$and $\mathrm{B}(\mathrm{OH})_{4}{ }^{-}$to $\mathrm{OH}^{-}$. 


\begin{tabular}{|c|c|c|c|c|c|c|c|c|c|c|c|c|}
\hline Mineral & Mineral formula & $\begin{array}{l}\text { Primary (P) - } \\
\text { secondary }(\mathrm{S})\end{array}$ & $\stackrel{2}{1}^{2}$ & $\begin{array}{l}50 \\
1\end{array}$ & 100 & 15 & & $\stackrel{200}{l}$ & $\stackrel{250}{\mathbf{I}}$ & $\begin{array}{c}300 \\
1\end{array}$ & $\stackrel{350}{1}$ & $\stackrel{400^{\circ} \mathrm{C}}{\mathrm{I}}$ \\
\hline Actinolite $^{3}$ & $\mathrm{Ca}_{2} \mathrm{Fe}_{5} \mathrm{Si}_{8} \mathrm{O}_{22}(\mathrm{OH})_{2}$ & S & & & & & & & & & & \\
\hline $\begin{array}{l}\text { Albite } 5,9 \\
\text { Analcime }^{9}\end{array}$ & $\begin{array}{c}\mathrm{NaAlSi}_{3} \mathrm{O}_{8} \\
\left.\mathrm{NaAlSi}_{2} \mathrm{O}_{6} \mathrm{H}_{2} \mathrm{O}\right)\end{array}$ & $\mathrm{P}, \mathrm{S}$ & & & & & & & & & & \\
\hline $\begin{array}{l}\text { Analcime }{ }^{9} \\
\text { Anhydrite }\end{array}$ & $\begin{array}{c}\mathrm{NaAlSi}_{2} \mathrm{O}_{6}\left(\mathrm{H}_{2} \mathrm{O}\right) \\
\mathrm{CaSO}_{4}\end{array}$ & $\begin{array}{l}S \\
S\end{array}$ & - & - & - & - & - & - & - & - & - & - \\
\hline Ankerite & $\mathrm{CaFe}\left(\mathrm{CO}_{3}\right)_{2}$ & $\mathrm{~s}$ & - & - & - & - & - & - & - & - & - & - \\
\hline Anorthite & $\mathrm{CaAl}_{2} \mathrm{Si}_{2} \mathrm{O}_{8}$ & $\mathrm{P}$ & - & - & - & - & - & - & - & - & - & - \\
\hline Calcite $^{3}$ & $\mathrm{CaCO}_{3}$ & $\mathrm{~s}$ & & & & & & & & & & \\
\hline Chabazite $^{9, d}$ & $\left(\mathrm{Ca}_{0 .}, \mathrm{Na}\right)_{2} \mathrm{Al}_{2} \mathrm{Si}_{4} \mathrm{O}_{12}\left(\mathrm{H}_{2} \mathrm{O}\right)_{6}$ & $\mathrm{~s}$ & $\longrightarrow$ & 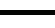 & & & & & & & & \\
\hline Chalcedony $^{3}$ & $\mathrm{SiO}_{2}$ & $\mathrm{~s}$ & & & & & & & & & & \\
\hline Chlorite 11,13 & $(\mathrm{Mg}, \mathrm{Fe})_{5} \mathrm{Al}_{2} \mathrm{Si}_{3} \mathrm{O}_{10}(\mathrm{OH})_{8}$ & $\mathrm{~s}$ & & & & & & & & & & \\
\hline Clinozoisite $^{3}$ & $\mathrm{Ca}_{2} \mathrm{Al}_{3}\left(\mathrm{SiO}_{4}\right)_{3}(\mathrm{OH})$ & $\mathrm{s}$ & - & 工 & 工 & 工 & & & & & & \\
\hline $\begin{array}{l}\text { Diopside } \\
\text { Dolomite }^{5}\end{array}$ & $\mathrm{CaMgSi}_{2} \mathrm{O}_{6}$ & $\mathrm{P}$ & - & - & 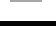 & - & - & - & - & - & - & - \\
\hline $\begin{array}{l}\text { Dolomite } \\
\text { Enstatite }\end{array}$ & $\begin{array}{c}\mathrm{CaMg}\left(\mathrm{CO}_{3}\right)_{2} \\
\mathrm{Mg}_{2} \mathrm{Si}_{2} \mathrm{O}_{6}\end{array}$ & $\begin{array}{l}S \\
P\end{array}$ & - & - & - & - & - & - & - & - & - & - \\
\hline Epidote $^{3,5}$ & $\mathrm{Ca}_{2}\left(\mathrm{Fe}^{3+}, \mathrm{Al}_{3}\right)_{3}\left(\mathrm{SiO}_{4}\right)_{3}(\mathrm{OH})$ & s & & & & & & & & & & \\
\hline Ferrosilite & $\mathrm{Fe}_{2} \mathrm{Si}_{2} \mathrm{O}_{6}$ & $\mathrm{P}$ & 一 & 一 & - & - & - & - & - & 一 & - & - \\
\hline Hematite & $\mathrm{Fe}_{2} \mathrm{O}_{3}$ & s & 一 & 一 & 一 & - & - & - & - & 一 & 一 & - \\
\hline Heulandite $e^{3,9}$ & $\left(\mathrm{Ca}_{0.5}, \mathrm{Na}_{2}\right)_{2} \mathrm{Al}_{2}^{2} \mathrm{Si}_{7}^{3} \mathrm{O}_{18}\left(\mathrm{H}_{2} \mathrm{O}\right)_{6}$ & s & & & & & & & & & & \\
\hline Ilmenite & $\mathrm{FeTiO}_{3}$ & $\mathrm{P}$ & 一 & 一 & - & - & - & - & - & - & - & - \\
\hline Kaolinite $^{5}$ & $\mathrm{Al}_{2} \mathrm{Si}_{2} \mathrm{O}_{5}(\mathrm{OH})_{4}$ & $\mathrm{~s}$ & & & & & & & & & & \\
\hline Laumontite 3,5 & $\mathrm{CaAl}_{2} \mathrm{Si}_{4} \mathrm{O}_{12}\left(\mathrm{H}_{2} \mathrm{O}\right)_{4.5}$ & s & & & & & & & & & & \\
\hline Leonhardite & $\mathrm{CaAl}_{2} \mathrm{Si}_{4} \mathrm{O}_{12}\left(\mathrm{H}_{2} \mathrm{O}\right)_{3.5}$ & $\mathrm{~s}$ & - & - & - & - & - & - & - & - & - & - \\
\hline Magnesite & $\mathrm{MgCO}_{3}$ & s & - & - & - & - & - & - & - & - & - & - \\
\hline Magnetite & $\mathrm{FeFe}_{3}+{ }_{2} \mathrm{O}_{4}$ & $\mathrm{P}, \mathrm{S}$ & - & - & - & - & - & - & - & - & - & - \\
\hline Mesolite & $\mathrm{Ca}_{0.67} \mathrm{Na}_{0.66} \mathrm{Al}_{2} \mathrm{Si}_{3} \mathrm{O}_{10}\left(\mathrm{H}_{2} \mathrm{O}\right)_{2.67}$ & s & - & - & - & - & - & - & - & - & - & - \\
\hline Microcline & $\mathrm{KAlSi}_{3} \mathrm{O}_{8}$ & $\mathrm{~s}$ & - & - & - & - & - & - & - & - & - & $=$ \\
\hline Montmorillonite ${ }^{5, c}$ & $\left(\mathrm{Ca}_{0.5}, \mathrm{Mg}_{0.5}, \mathrm{~K}, \mathrm{Na}\right)_{0.33} \mathrm{Mg}_{0.33}(\mathrm{Al})_{1.67} \mathrm{Si}_{4} \mathrm{O}_{10}(\mathrm{OH})_{2}$ & s & & & & & & & & & & \\
\hline Mordenite $^{7,9}$ & $\left(\mathrm{Ca}_{0.5} \mathrm{Na}^{\mathrm{NalSi}} \mathrm{Al}_{5} \mathrm{O}_{12}\left(\mathrm{H}_{2} \mathrm{O}\right)_{4}\right.$ & $\mathrm{s}$ & & & 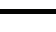 & - & & & & & & \\
\hline Muscovite $^{11}$ & $\mathrm{KAl}_{2}\left(\mathrm{AlSi}_{3}\right) \mathrm{O}_{10}(\mathrm{OH})_{2}$ & $\mathrm{~s}$ & & & & & & & & & & \\
\hline Natrolite & $\mathrm{Na}_{2} \mathrm{Al}_{2} \mathrm{Si}_{3} \mathrm{O}_{10}\left(\mathrm{H}_{2} \mathrm{O}\right)_{2}$ & $\mathrm{~s}$ & - & - & 一 & - & - & - & - & - & 一 & - \\
\hline Olivine & $(\mathrm{Fe}, \mathrm{Mg})_{2} \mathrm{SiO}_{4}$ & $\mathrm{P}$ & 一 & - & - & - & - & - & - & - & - & - \\
\hline Prehnite $^{3,5}$ & $\mathrm{Ca}_{2} \mathrm{Al}_{2} \mathrm{Si}_{3} \mathrm{O}_{10}(\mathrm{OH})_{2}$ & $\mathrm{~s}$ & & & & & & & & & & \\
\hline Pyrite & $\mathrm{FeS}_{2}$ & $\mathrm{~s}$ & - & - & - & - & - & — & - & - & - & - \\
\hline Pyrrhotite ${ }^{1,6}$ & $\mathrm{Fe}^{3+}{ }_{0.2} \mathrm{Fe}_{0.7}^{2} \mathrm{~S}$ & S & & & & & & & & & & \\
\hline Quartz $^{10}$ & $\mathrm{SiO}_{2}$ & $\mathrm{~s}$ & & & & & & & & & & \\
\hline Rutile & $\mathrm{TiO}_{2}^{2}$ & $\mathrm{~s}$ & — & - & - & - & - & - & - & - & - & - \\
\hline Scolecite & $\mathrm{CaAl}_{2} \mathrm{Si}_{3} \mathrm{O}_{10}\left(\mathrm{H}_{2} \mathrm{O}\right)_{3}$ & $\mathrm{~s}$ & - & - & - & - & - & - & - & - & - & - \\
\hline Siderite & $\mathrm{FeCO}_{3}$ & $\mathrm{~s}$ & - & - & - & - & - & - & - & - & - & - \\
\hline Smectite-Dio. ${ }^{11, a}$ & $\left(\mathrm{Ca}_{0.5}, \mathrm{Mg}_{0.5}, \mathrm{~K}, \mathrm{Na}\right)_{0.33}\left(\mathrm{Al}, \mathrm{Fe}^{3+}\right)_{2} \mathrm{Al}_{0.33} \mathrm{Si}_{3.67} \mathrm{O}_{10}(\mathrm{OH})_{2}$ & s & & & & & & & & & & \\
\hline Smectite-Trio. ${ }^{11,13, b}$ & $\left(\mathrm{Ca}_{0.5}, \mathrm{Mg}_{0.5}, \mathrm{~K}, \mathrm{Na}\right)_{0.33}\left(\mathrm{Mg}, \mathrm{Fe}_{3} \mathrm{Al}_{0.33} \mathrm{Si}_{3.67} \mathrm{O}_{10}(\mathrm{OH})_{2}\right.$ & s & & & & & & & & & & \\
\hline $\begin{array}{l}\text { Stilbite } 5,9 \\
\text { Tala }^{2,12}\end{array}$ & $\mathrm{CaAl}_{2} \mathrm{Si}_{7} \mathrm{O}_{18}\left(\mathrm{H}_{2} \mathrm{O}\right)_{7}$ & $\mathrm{~s}$ & & & & & & & & & & \\
\hline $\mathrm{Talc}^{2,12}$ & $\mathrm{Mg}_{3} \mathrm{Si}_{4} \mathrm{O}_{10}(\mathrm{OH})_{2}$ & $\mathrm{~s}$ & & & & & & & & & & \\
\hline Thomsonite & $\mathrm{Ca}_{2} \mathrm{NaAl}_{5} \mathrm{Si}_{5} \mathrm{O}_{20}\left(\mathrm{H}_{2} \mathrm{O}\right)_{6}$ & $\mathrm{~s}$ & - & - & - & - & - & - & - & - & - & - \\
\hline Titanite & $\mathrm{CaTiSiO}_{5}$ & s & - & - & - & $=$ & - & - & - & - & - & $=$ \\
\hline Wairakite $^{8,9}$ & $\mathrm{CaAl}_{2} \mathrm{Si}_{4} \mathrm{O}_{12}\left(\mathrm{H}_{2} \mathrm{O}\right)_{2}$ & $\mathrm{~s}$ & & & & & & & & & & \\
\hline
\end{tabular}

FIGURE 1: Temperature stability constraints for minerals occurring in hydrothermally altered mid-ocean ridge basalts. Full black lines: upper and/or lower stability constraints of the phase added in the code according to alteration mineralogy data after ${ }^{1}$ Arnold et al. [39], ${ }^{2}$ Lonsdale et al. [40], ${ }^{3}$ Henley and Ellis [41], ${ }^{4}$ Jenkins et al. [42], ${ }^{5}$ Reyes [43], ${ }^{6}$ Hannington et al. [44], ${ }^{7}$ White and Hedenquist [45], ${ }^{8}$ Jové and Hacker [46], ${ }^{9}$ Chipera and Apps [47], ${ }^{10}$ Bird and Spieler [48], ${ }^{11}$ Monecke et al. [49], ${ }^{12}$ Hodgkinson et al. [50], and ${ }^{13}$ Thien et al. [51]. Dashed grey lines: nonconstrained mineral phase. Ideal solid solution endmembers: ${ }^{\mathrm{a}} \mathrm{Ca}$-beidellite, Ca-nontronite, Mg-beidellite, Mg-nontronite, $\mathrm{K}$-beidellite, K-nontronite, Na-beidellite, and Na-nontronite; ${ }^{\mathrm{b}} \mathrm{Ca}$-saponite, Fe-saponite, Mg-saponite, K-saponite, and Na-saponite; ${ }^{\mathrm{c} C a}$ montmorillonite, Mg-montmorillonite, K-montmorillonite, and Na-montmorillonite; and ${ }^{\mathrm{d}} \mathrm{Ca}$-chabazite and Na-chabazite.

The upper temperature limit of the model corresponds to the highest vent temperature observed in mid-ocean ridge hydrothermal systems $\left(405-407^{\circ} \mathrm{C}\right)[19,57]$. A fixed pressure of 500 bars was used in the simulations to take into account the hydrostatic pressure prevailing in the reaction zone of mid-ocean ridge hydrothermal systems, assuming an average water depth of $2500 \mathrm{~m}$ [58] and a distance of $2500 \mathrm{~m}$ between the seafloor and the top of the axial magma chamber $[59,60]$. Because previous studies have established that the F/R ratio varies from approximately 1 to 100 by mass in mid-ocean ridge hydrothermal systems $[2,9,21-24]$, the numerical simulations were carried out using $\mathrm{F} / \mathrm{R}$ mass ratios of $1,5,20,50$, 70 , and 100 . These ratios were achieved by reacting $1 \mathrm{~kg}$ of rock with the required amount of seawater and are thus defined as the total weight of seawater that will equilibrate in the system to the weight of unreacted rock.

2.3. Model Assumptions. In the numerical simulations, alteration minerals were allowed to precipitate during fluid/rock interaction upon reaching saturation and partial equilibrium with the aqueous fluid. This model is similar to the classical irreversible reaction of feldspar hydrolysis by Helgeson [61] and Helgeson et al. [62], where a series of partial equilibria take place upon continued reaction progress of feldspar dissolution until the mineral-fluid system reaches an overall equilibrium. However, complex multicomponentmultiphase systems are more difficult to predict, as saturation may be reached with several of the primary igneous minerals depending on temperature [63], as well as with secondary minerals upon rock alteration. This implies that certain primary minerals such as olivine will only dissolve until they reach saturation but will not reprecipitate, whereas others such as feldspar may dissolve and reprecipitate to form secondary feldspar with a different composition, as observed in natural geothermal systems [64].

The precipitation of certain low-temperature alteration minerals, particularly sheet silicates and zeolites, may be inhibited by slower reaction kinetics. As a result, the simulations may predict the formation of stable mineral phases that are not observed in nature for a given temperature. For 
TABLE 1: Average MORB and seawater compositions integrated in the calculations of this study.

\begin{tabular}{|c|c|c|c|}
\hline \multicolumn{2}{|c|}{$\begin{array}{l}\text { Average MORB } \\
\text { composition }^{1}\end{array}$} & \multicolumn{2}{|c|}{ Seawater composition $^{2}$} \\
\hline & wt $\%$ & & Solution $(\mathrm{mol} / \mathrm{kg})$ \\
\hline $\mathrm{SiO}_{2}$ & 50.43 & $\mathrm{Na}^{+}$ & 0.469 \\
\hline $\mathrm{TiO}_{2}$ & 1.49 & $\mathrm{Mg}^{2+}$ & 0.0528 \\
\hline $\mathrm{Al}_{2} \mathrm{O}_{3}$ & 15.37 & $\mathrm{Ca}^{2+}$ & 0.0104 \\
\hline $\mathrm{FeO}$ & 8.95 & $\mathrm{~K}^{+}$ & 0.0102 \\
\hline $\mathrm{Fe}_{2} \mathrm{O}_{3}$ & 1.84 & $\mathrm{Cl}^{-}$ & 0.5467 \\
\hline $\mathrm{MgO}$ & 7.58 & $\mathrm{SO}_{4}{ }^{2-}$ & 0.0282 \\
\hline $\mathrm{CaO}$ & 11.53 & $\mathrm{HCO}_{3}^{-}$ & 0.0017 \\
\hline $\mathrm{Na}_{2} \mathrm{O}$ & 2.54 & $\mathrm{CO}_{3}{ }^{2-}$ & $2.4 \times 10^{-4}$ \\
\hline $\mathrm{K}_{2} \mathrm{O}$ & 0.14 & $\mathrm{~F}^{-}$ & $6.8 \times 10^{-5}$ \\
\hline S & 0.13 & $\mathrm{OH}^{-}$ & $1.09 \times 10^{-4}$ \\
\hline \multirow[t]{3}{*}{$\mathrm{Fe}^{3+} / \Sigma \mathrm{Fe}$} & 0.1563 & $\mathrm{CO}_{2}$ & $9.5 \times 10^{-6}$ \\
\hline & & $\mathrm{H}_{2} \mathrm{O}$ & 53.5565 \\
\hline & & $\mathrm{pH}$ & 8.1 \\
\hline
\end{tabular}

${ }^{1}$ Average composition of eight MORB glasses from the East Pacific Rise, Mid-Atlantic Ridge, Galapagos Spreading Center, and Juan de Fuca Ridge (data after Kelley and Cottrell [55] and reference therein). ${ }^{2}$ Seawater composition modified from the reference composition of Millero et al. [56], defined at $t=25^{\circ} \mathrm{C}, P=1 \mathrm{~atm}$, and a salinity of $35 \mathrm{~g} / \mathrm{kg}$.

instance, the numerical simulations predict trioctahedral smectites and chlorite to be stable across the entire temperature range considered in the model. This contradicts observations made in natural systems, where smectite represents a predominant alteration mineral in basaltic environments at temperatures $<150-200^{\circ} \mathrm{C}$, whereas chlorite is known to form at higher temperatures $[49,65]$. For this reason, upper and/or lower temperature metastability constraints were added in the code for the precipitation of minerals according to the alteration mineralogy observed in natural systems. The primary and secondary minerals considered in the simulations are listed in Figure 1.

\section{Results}

3.1. Simulated Alteration Mineralogy. A summary of the alteration mineralogy obtained from the simulation of seawater-basalt interaction is presented in Figure 2. Both the temperature and the $\mathrm{F} / \mathrm{R}$ ratio have a principal control on the predicted mineral assemblages. The overall reaction path can be exemplified by the results obtained at an $\mathrm{F} / \mathrm{R}$ ratio of 1 . At low temperature $\left(<200^{\circ} \mathrm{C}\right)$, Na-Ca-bearing zeolites, trioctahedral (Ca)-Mg-Fe-bearing smectites, and calcite were stable, whereas at high temperature $\left(>200^{\circ} \mathrm{C}\right)$, these minerals were replaced by chlorite-( $\mathrm{Mg}-\mathrm{Fe})$, albite, quartz, and Ca-bearing aluminosilicates, including epidote, wairakite, prehnite, and clinozoisite. Trioctahedral (Ca)-Mg-Febearing smectites were replaced by chlorite-( $\mathrm{Mg}-\mathrm{Fe})$ at high temperature, illustrating a competition for $\mathrm{Mg}$ and $\mathrm{Fe}$ between these minerals. A sharp discontinuity can be observed in the model at $200^{\circ} \mathrm{C}$ due to the temperature constraints of mineral precipitation used for the sheet silicates and zeolites. Scolecite, thomsonite, and calcite constitute the stable alteration minerals competing for $\mathrm{Ca}$ at low temperature, followed by their progressive replacement by epidote, wairakite, and prehnite with increased temperature. The Ca-bearing mineral clinozoisite was stabilized at high temperature, between 370 and $380^{\circ} \mathrm{C}$. In the group of Nabearing minerals, natrolite was stable at low temperature and replaced by analcime above $100^{\circ} \mathrm{C}$, followed by albite above $200^{\circ} \mathrm{C}$. Smectite-(K) was the only K-bearing mineral formed in the simulations. Hematite was stable up to $200^{\circ} \mathrm{C}$ and pyrite up to $310^{\circ} \mathrm{C}$, where it became replaced by pyrrhotite. Titanite was the only stable Ti-bearing mineral present at all temperatures.

The number of minerals formed at a given temperature varied with the $F / R$ ratio. At low $F / R$ ratios $(F / R<50)$, representing rock-buffered conditions, a larger number of alteration minerals were formed with complex competing reactions among low-temperature zeolites and hightemperature $\mathrm{Ca}-\mathrm{Al}-\mathrm{Si}$-bearing minerals (epidote, prehnite, and clinozoisite). At high $\mathrm{F} / \mathrm{R}$ ratios $(\mathrm{F} / \mathrm{R}>50)$, representing seawater-buffered conditions, the total number of alteration minerals decreased and relatively simple mineral alteration assemblages were formed. Albite progressively decreased towards higher $\mathrm{F} / \mathrm{R}$ ratios until disappearing completely at a $\mathrm{F} / \mathrm{R}$ value of 100 above $325^{\circ} \mathrm{C}$. Kaolinite appeared towards higher $\mathrm{F} / \mathrm{R}$ ratios at the expense of the $\mathrm{Na}$-Ca-bearing zeolites such as natrolite and scolecite. Increasing amounts of anhydrite were formed towards higher F/R ratios in competition with other Ca-bearing minerals such as epidote and wairakite until $\mathrm{F} / \mathrm{R}$ values of $>50$ were reached, where all the $\mathrm{Ca}$ was consumed by the precipitation of anhydrite. Talc was present at relatively high $\mathrm{F} / \mathrm{R}$ ratios $(\mathrm{F} / \mathrm{R}$ of 50 and 70 ) and was accompanied at low temperature by the replacement of calcite by ankerite. Hematite and pyrite increased progressively towards higher $\mathrm{F} / \mathrm{R}$ ratios at low temperature, while at high temperature, hematite was absent and pyrite decreased until disappearing at a F/R value of 20. Pyrrhotite was replaced by magnetite at a F/R value of 5 and rutile replaced titanite at a $\mathrm{F} / \mathrm{R}$ value of 50 . The amounts of chlorite, smectites, and quartz were not significantly influenced by the $\mathrm{F} / \mathrm{R}$ ratio.

3.2. Simulated Fluid Evolution. Both the temperature and the $\mathrm{F} / \mathrm{R}$ ratio also affect the calculated seawater chemistry during interaction with basaltic rocks. Figure 3 shows the modeled fluid composition for dissolved $\mathrm{Mg}, \mathrm{Ca}, \mathrm{Na}$, and $\mathrm{K}$ concentrations and $\mathrm{pH}$ and $\mathrm{Eh}$ (redox potential) in comparison to the initial composition of unreacted seawater $\left(\mathrm{Sw}_{2}{ }^{\circ} \mathrm{C}\right)$. The discontinuity occurring at $200^{\circ} \mathrm{C}$ is analogous to that obtained in the secondary mineralogy and results from the mineral metastability constraints used for smectites and chlorite, as described above.

The $\mathrm{Mg}$ concentration of the simulated fluids was very low at low temperature and low $F / R$ ratios $(F / R$ of $<50)$ and increased with higher temperature and $\mathrm{F} / \mathrm{R}$ ratio $(\mathrm{F} / \mathrm{R}$ of $>50$ ). At high $\mathrm{F} / \mathrm{R}$ ratios ( $\mathrm{F} / \mathrm{R}$ value of 100 ), the $\mathrm{Mg}$ concentration of the fluids was several orders of magnitude higher and approached the concentration of unreacted seawater. The mobility of $\mathrm{Mg}$ was controlled by the stability of trioctahedral smectite- $(\mathrm{Mg})$ at low temperature and by 

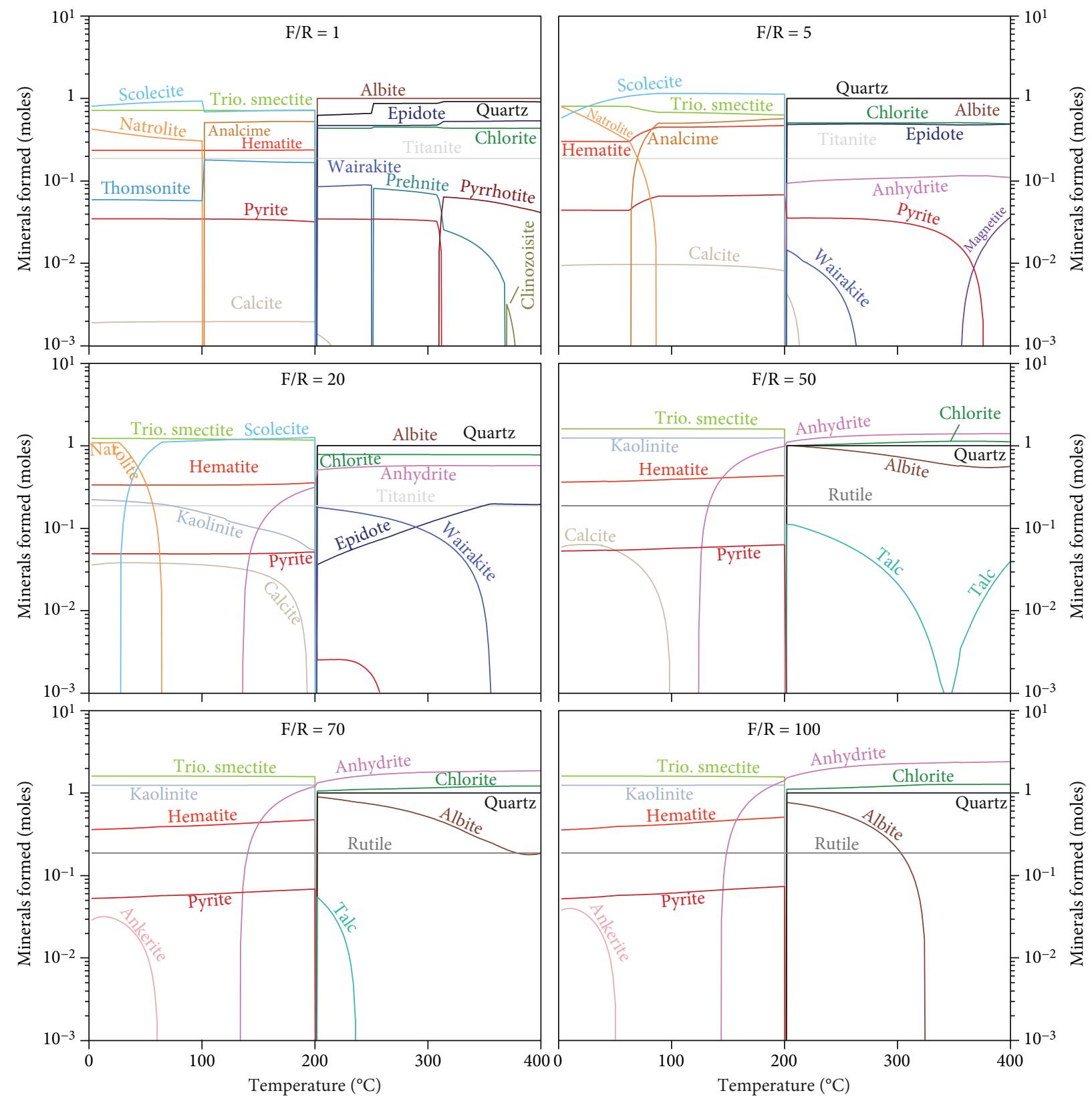

FIGURE 2: Simulated stable mineralogy (in moles) formed during seawater-basalt interaction from 2 to $400^{\circ} \mathrm{C}, 500$ bars, and variable fluid/rock $(\mathrm{F} / \mathrm{R})$ mass ratios representative of conditions documented at mid-ocean ridges.

chlorite-( $\mathrm{Mg})$ at high temperature. The increase of $\mathrm{Mg}$ in the fluids at high temperature and low F/R ratios relates to the lower amounts of chlorite precipitation at these conditions in comparison to the amounts of smectites formed at low temperature (Figures 2 and 3). At higher F/R ratios, the large volumes of reacted seawater involved in the system preserved high $\mathrm{Mg}$ concentrations, while large quantities of smectites and chlorite were predicted to precipitate.

The mobility of Ca was controlled by the stability of carbonates, zeolites, and smectites at low temperature and by anhydrite, epidote, wairakite, prehnite, and clinozoisite at high temperature. The highest concentrations of dissolved Ca were achieved at low $\mathrm{F} / \mathrm{R}$ ratios for all temperatures except between $\sim 50$ and $200^{\circ} \mathrm{C}$ (Figures 2 and 3). The diverging fluid evolution for dissolved Ca between $\sim 50$ and $200^{\circ} \mathrm{C}$ can be related to the excessive uptake of $\mathrm{Ca}$ by scolecite. The decrease of dissolved $\mathrm{Ca}$ with increasing $\mathrm{F} / \mathrm{R}$ ratios at temperatures above $120^{\circ} \mathrm{C}$ was caused by the precipitation of anhydrite at these conditions (Figures 2 and 3 ).

The mobility of $\mathrm{Na}$ was controlled by the stability of zeolites and smectites at low temperature and by albite at high temperature (Figures 2 and 3). The concentration of $\mathrm{Na}$ of the simulated fluid did not vary significantly with temperature and remained within the range of the unreacted seawater value after seawater-basalt interaction. At low $\mathrm{F} / \mathrm{R}$ ratios, a slight enrichment of $\mathrm{Na}$ was observed in 


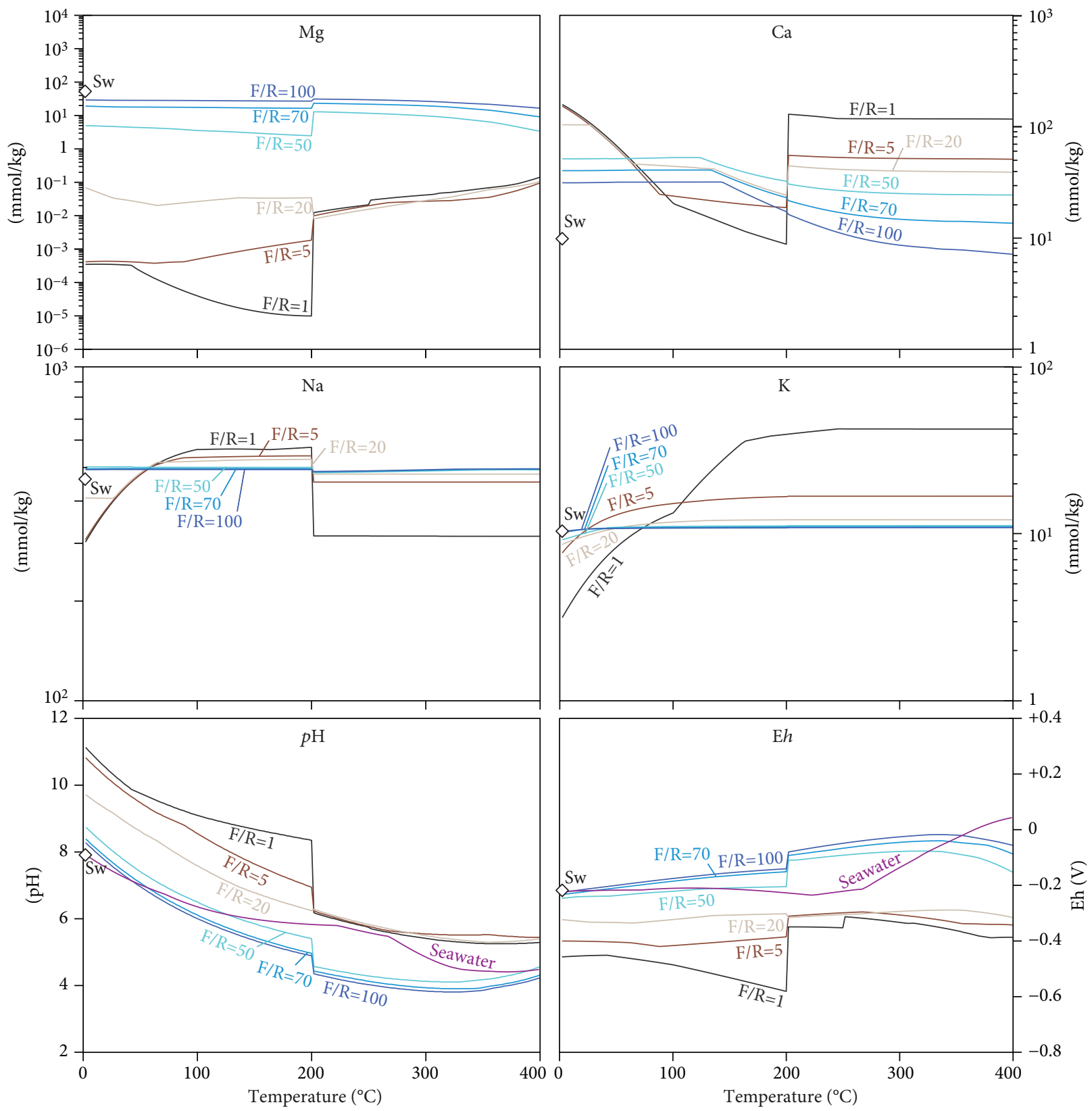

Figure 3: Simulated fluid composition in total dissolved $\mathrm{Mg}, \mathrm{Ca}, \mathrm{Na}$, and $\mathrm{K}$ (in $\mathrm{mmol} / \mathrm{kg}$ ) with $\mathrm{pH}$ and Eh following seawater-basalt interaction from 2 to $400^{\circ} \mathrm{C}, 500$ bars, and variable fluid/rock (F/R) mass ratios. White diamonds represent the composition of seawater at $2^{\circ} \mathrm{C}$ (see Table 1). The purple curves represent the $\mathrm{pH}$ and Eh evolutions of heated seawater alone.

the simulated fluid below $200^{\circ} \mathrm{C}$, while a slight decrease in $\mathrm{Na}$ was observed at temperatures above $200^{\circ} \mathrm{C}$ due to the formation of albite over Na zeolites.

The mobility of $\mathrm{K}$ was controlled by the stability of smectite-(K) at low temperature, while $\mathrm{K}$ was not transferred from the primary minerals to the alteration assemblage at high temperature (Figures 2 and 3). The concentrations of dissolved $\mathrm{K}$ at high $\mathrm{F} / \mathrm{R}$ ratios are comparable to the value of this element in unreacted seawater. However, at low F/R ratios and temperatures below $120^{\circ} \mathrm{C}$, the dissolved concentrations of $\mathrm{K}$ were lower, whereas above $120^{\circ} \mathrm{C}$, these values exceeded unreacted seawater concentrations.
The simulated $\mathrm{pH}$ varied significantly in the simulations and is characterized by an overall decrease with increasing temperature and fluid/rock ratios (Figure 3). At low temperature and low $\mathrm{F} / \mathrm{R}$ values, the fluid is characterized by alkaline conditions reaching $\mathrm{pH}$ values of $\sim 10$ to 11 , consistent with the formation of zeolites and calcite as major alteration minerals. Increasing $\mathrm{F} / \mathrm{R}$ values to $>50$ caused a moderate shift of the $\mathrm{pH}$ to values reaching between $\sim 8.5$ and 9 . Increasing temperatures to $400^{\circ} \mathrm{C}$ led to a considerable $\mathrm{pH}$ decrease with values reaching close to 6 at low $F / R$ ratios and values close to 4 at high $\mathrm{F} / \mathrm{R}$ ratios. These lower $\mathrm{pH}$ values are in agreement with the stability of kaolinite at these 
conditions. The overall decreasing trend of $\mathrm{pH}$ with temperature can be related to the increased endothermic ionization of pure water into $\mathrm{H}^{+}$and $\mathrm{OH}^{-}$, which translates into an increased dissociation constant $\left(K_{\mathrm{w}}\right)$ towards higher temperatures. This process shifts the neutral $\mathrm{pH}$ value from 7 at room temperature to $\sim 5.5$ at $200^{\circ} \mathrm{C}$ and back to $\sim 6.1$ at $400^{\circ} \mathrm{C}$. In addition to the shift of neutral $\mathrm{pH}$ for pure water, the increase in temperature causes seawater to become more acidic due to the precipitation of anhydrite and magnesium hydroxide sulfate hydrate [66] between 180 and $400^{\circ} \mathrm{C}$ and to the increased association of $\mathrm{OH}^{-}$-bearing aqueous complexes. The $\mathrm{pH}$ curve of seawater, shown in Figure 3, is similar to the one obtained by Bischoff and Seyfried [5]. The simulated $\mathrm{pH}$ resulting from fluid/rock interaction follows a similar trend, but either plots above/below this curve, yielding more alkaline/acidic conditions, respectively. These changes can result from a combination of ionization of the acids, and the overall reaction progress of fluid/rock interaction, which involves proton $\left(\mathrm{H}^{+}\right)$consumption and cation release upon dissolution of primary minerals and dissolution-precipitation of secondary minerals.

The simulated redox potential (Eh) of seawater reacted with basalt is characterized by an overall increase with increasing temperatures and fluid/rock ratios (Figure 3) and by an overall shift towards negative Eh values in comparison to the initial value of unreacted seawater $\left(\mathrm{Eh}_{\mathrm{Sw}, 2^{\circ} \mathrm{C}}=-0.22 \mathrm{~V}\right)$. The simulated Eh values were observed to decrease from $\sim 0 \mathrm{~V}$ at high fluid/rock ratios to almost $-0.6 \mathrm{~V}$ at low fluid/ rock ratios, indicating that increased rock buffering will cause more reduced conditions in the chemical system. The redox potential of the system is buffered by the initial $\mathrm{Fe}^{3+} / \sum \mathrm{Fe}$ ratio of the rock and by the oxidation state of the secondary minerals formed in the simulations. The mobility of $\mathrm{Fe}$ is controlled by the stability of hematite, pyrite, pyrrhotite, magnetite, epidote, and ankerite. A decrease in Eh values is related to the precipitation of larger amounts of Fe(II)-bearing minerals such as pyrite, pyrrhotite, and magnetite relative to Fe(III)-bearing minerals such as hematite.

\section{Discussion}

4.1. Influence of Rock Crystallinity. The oceanic crust at midocean ridges consists of a $\sim 0.5 \mathrm{~km}$ thick upper succession of glassy-to-finely crystalline basalts forming pillows, massive flows and breccias, a $\sim 1.5 \mathrm{~km}$ thick sheeted dike complex composed of diabase, and a several $\mathrm{km}$ thick basal succession of coarse-grained gabbroic rocks [9, 67]. These rocks are characterized by a similar major element composition, but vary in texture and mineralogy, which may affect the rate and stoichiometry of ionic exchange, particularly at low temperature where mineral dissolution may be controlled by reaction kinetics $[29,31,68-72]$. Even if reaction kinetics is of key importance for basalt alteration at lower temperatures [73-76], its relative importance with respect to fluid/ rock equilibria processes is somewhat unclear. To answer these questions, the effects of temperature, fluid and rock compositions, and extent of reaction ( $\mathrm{F} / \mathrm{R}$ ratios) need to be studied separately.
Previous experimental and modeling work on the alteration of both glassy and crystalline mafic rocks suggests that although basaltic glass dissolves faster than more crystalline basaltic rocks [77], the crystallinity of the protolith has only a limited influence on the formation of secondary minerals when approaching fluid/rock equilibria at hydrothermal conditions [51, 71, 78-82]. Similar observations have been made in Iceland, where low temperature alteration products of volcanic glasses have similar compositions to those formed during the alteration of crystalline rocks on longer geological timescales $[83,84]$. This suggests that the relatively small volume of basaltic glass present at shallow depths beneath mid-ocean ridges may have a similar influence on the overall chemical mass balance associated to fluid/rock interaction as crystalline basalts of the same composition.

\subsection{Comparison of the Simulated Alteration Mineralogy to} Natural Systems. The nature and distribution of alteration minerals present in mid-ocean ridge hydrothermal systems is difficult to constrain as this would involve the deep drilling of active seafloor hydrothermal systems, where coexistence of hydrothermal fluids and rocks can be assured. However, it is well known that the alteration mineralogy and chemical composition of fluids in hydrothermal systems at close to equilibrium conditions are essentially determined by the initial chemical composition of the fluids, rock composition, and temperature $[85,86]$. Therefore, similar alteration patterns can be expected to occur in similar petrogenetical settings, as indicated by previous studies [41, 48, 87]. Additional information on the nature of the minerals present in equilibrium with hydrothermal solutions in mid-ocean ridge hydrothermal systems can hence be obtained from active basalt-hosted geothermal systems where the rock composition and temperature range are analogous.

The formation of zeolites at low temperature in the simulations is consistent with the occurrence of these minerals as low grade alteration products in volcanic environments [88, 89]. Scolecite occurs in the early and intermediate stages of burial metamorphism of basaltic lavas in Iceland [88]. Natrolite, analcime, and thomsonite are typically found as alteration products of mafic rocks, where they develop within late stage alteration assemblages $[47,90]$. The appearance of wairakite at high temperature in the model is supported by the presence of this mineral in active geothermal systems of New Zealand at temperatures exceeding $200^{\circ} \mathrm{C}[48,91]$. The formation of calcic zeolite is favored with increasing degrees of alteration, particularly in mafic rocks, due to the rise of $\mathrm{Ca}-\mathrm{Na}$ activity ratios resulting from the progressive albitization of calcic plagioclase [92].

Trioctahedral smectites were also predicted to form in the low temperature section of the model. This is consistent with observations made in natural volcanic environments, where smectites commonly occur as an alteration product of volcanic glasses and from the breakdown of olivine, pyroxene, and feldspar [93]. The transition between trioctahedral smectites and chlorite was constrained to occur at $200^{\circ} \mathrm{C}$ in the present model due to the difficulties in reproducing intermediate metastable mixed-layer phases. In 
natural environments, the transformation from trioctahedral smectites to chlorite is more gradual and generally involves a continuous mixed-layer chlorite/smectite series or a discontinuous sequence consisting of smectite \pm corrensite \pm chlorite $[49,94,95]$. It is therefore expected that the major discontinuity observed in the model at $200^{\circ} \mathrm{C}$ is artificial and could not be corroborated by geochemical observations of natural systems, where this transition occurs over a temperature range of at least $50^{\circ} \mathrm{C}$ [49]. This artifact could be removed in future modeling efforts by the implementation of the thermodynamic data of these minerals and their intermediate phases.

The presence of kaolinite in the simulations is consistent with the occurrence of this mineral in several geothermal systems from Iceland, Japan, and New Zealand [48, 82, 96] as well as in submarine hydrothermal environments dominated by mafic rocks $[97,98]$. Kaolinite occurs in altered mafic to felsic volcanic rocks and characterizes cationdepleted fluid/rock equilibria at relatively acidic conditions $[43,48,99]$. The appearance of talc in the intermediate to high temperature range of the simulations does not have any analogs in active geothermal systems, where this mineral is only rarely observed. However, talc is present in submarine hydrothermal systems within active chimneys and massive sulfide mounds, where it was observed as secondary mineral precipitates $[50,100,101]$. Other low temperature minerals formed in the model include the carbonates calcite and ankerite. The precipitation of calcite is in agreement with the occurrence of this mineral in mafic rocks as infill of original open spaces such as vesicles and cements in volcaniclastic facies and as euhedral crystals replacing olivine and plagioclase [88, 102]. The low temperature occurrence of the Fe carbonate ankerite has been reported in young basalts from the Galápagos Spreading Center, where it is thought to be metastable [103], and from laboratory experiments [31]. Celadonite is widely documented as a product of low temperature alteration of basalt [9] and is also predicted to form in the model at temperatures between 2 and $170^{\circ} \mathrm{C}$, where it coprecipitates with dolomite. Dolomite has, however, not been observed in seafloor hydrothermal systems at low temperature [104], where its formation is likely inhibited by kinetic restrictions [105].

The simulated high temperature mineral assemblage characterized by epidote, albite, prehnite, and clinozoisite is consistent with the alteration mineralogy observed in natural systems. The presence of albite above the smectite-chlorite transition is in agreement with the occurrence of feldspar as an alteration phase in geothermal systems at temperatures exceeding $200^{\circ} \mathrm{C}$, where it forms by dissolution and replacement of primary plagioclase [64, 106-109]. Hydrothermal epidote and prehnite coexist in geothermal systems and represent common alteration products of volcanic rocks at temperatures above $230-260^{\circ} \mathrm{C}[43,48,110]$. Epidote and prehnite are typical of low temperature metamorphism, and the growth of these minerals sets the boundary between late stage diagenesis and metamorphism where volcanic glass is replaced by sheet silicates in subaerial hydrothermal systems [48, 111]. Clinozoisite occurs as a minor phase accompanying epidote within geothermal systems in zones of magmatic-hydrothermal alteration and contact metamorphism $[43,48]$.

Anhydrite is documented in most active geothermal systems where it precipitates over a broad range of temperatures [48] and is also a common component of chimney structures in submarine hydrothermal systems. Its pronounced retrograde solubility leads to dissolution in seawater if the high temperature fluid flow is interrupted or terminated [112]. Anhydrite was predicted to form in the model, but became unstable at temperatures below $\sim 150^{\circ} \mathrm{C}$. Pyrrhotite and pyrite have both been described from active black smoker chimneys and high temperature massive sulfides recovered from mid-ocean ridge vent fields $[44,113,114]$. The equilibrium mineral assemblage that is precipitated during mixing between the hydrothermal fluid and seawater depends to a large extent on the chemical buffering of hydrothermal fluids by fluid/rock interaction processes [13]. Fluids that are buffered to lower Eh values produce a pyrite-pyrrhotite-magnetite assemblage while fluids at higher Eh values precipitate only pyrite; pyrrhotite is also commonly replaced by pyrite at low temperature $[44,115,116]$.

\subsection{Comparison of the Simulated Fluid Chemistry to Icelandic} Waters. As described above, the modeled alteration mineralogy is consistent with the various mineral assemblages occurring as a result of basalt alteration in natural hydrothermal systems. The applicability of the model can also be tested through a comparison of the modeled fluid chemistry including the activities of $\mathrm{Mg}^{2+}, \mathrm{Ca}^{2+}$, and $\mathrm{Na}^{+}$with the measured concentrations of these elements in natural geothermal waters of Iceland (Figure 4) from the studies of Stefánsson et al. [63] and Stefánsson and Arnórsson [108]. A comparison between the simulated fluid chemistry resulting from seawater-basalt interaction at mid-ocean ridges and natural waters from the Icelandic geothermal systems is justified by the similar host basaltic rock composition and the nearly identical temperature range of the two hydrothermal environments. It has to be noted, however, that the starting fluid compositions are different, and that the geothermal systems in Iceland are mainly characterized by low chlorine concentrations, with only few exceptions that include variable amounts of mixing with seawater $[85,117]$.

The overall fluid/rock interaction presents analogies to a chemical titration process $[62,118]$, where the basalt acts as a base by consuming protons and releasing cations upon dissolution, while the fluid acts as an acid due to the presence of components containing ionizable hydrogen in seawater [5]. The cation to proton $\left(\mathrm{H}^{+}\right)$activity ratio of natural waters is a good indicator for this fluid/rock interaction process and yields information on the reaction progress associated to basalt alteration $[31,71,119]$. As a consequence, the cation to proton ratio will increase with increasing reaction progress or varying $\mathrm{F} / \mathrm{R}$ ratios at fixed temperature. Figure 4 shows these comparisons, where the variations of the cation to proton activity ratios for various simulated $\mathrm{F} / \mathrm{R}$ ratios reflect the combined effects of primary mineral dissolution and secondary mineral precipitation-dissolution reactions, as well as the release of protons from the ionization of the acids present in 

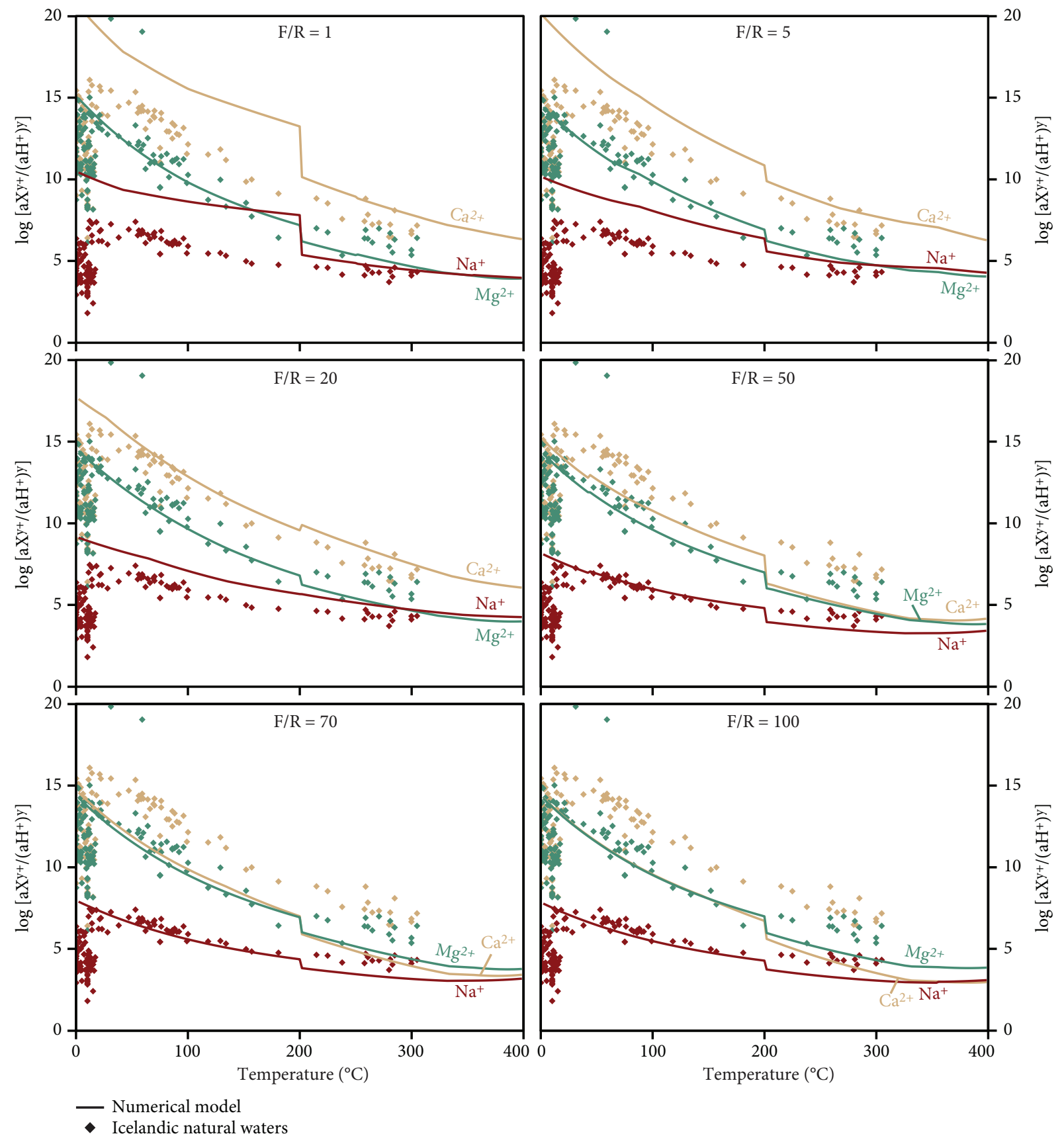

Figure 4: Comparison between simulated fluid composition (lines) and natural waters from Iceland (diamond symbols) showing selected cation to proton activity ratios as a function of temperature for variable fluid/rock (F/R) mass ratios. The seawater-basalt simulations were carried out from 2 to $400^{\circ} \mathrm{C}, 500$ bars, and variable fluid/rock mass ratios. The fluid compositions from the model possess near-seawater salinity values while Icelandic waters are characterized by low-salinity dilute meteoric spring waters and geothermal spring waters. Data for natural Icelandic waters from Stefánsson et al. [63] and Stefánsson and Arnórsson [108] (X= cation; y= cation charge).

the water followed by their neutralization by the rock. Notable variations can be observed in these simulations for $a \mathrm{Ca}^{2+}$ / $\left(a \mathrm{H}^{+}\right)^{2}$ and $a \mathrm{Na}^{+} / a \mathrm{H}^{+}$ratios as function of $\mathrm{F} / \mathrm{R}$ varying from 1 to 100 . The ratio $a \mathrm{Mg}^{2+} /\left(a \mathrm{H}^{+}\right)^{2}$, however, maintains constant values across the entire range of simulated $F / R$ ratios. This can be explained by the fact that $\mathrm{Mg}^{2+}$ is buffered by the stability of the sheet silicates (i.e., smectites and chlorite), which have a considerable control on $\mathrm{pH}$ and hence $a \mathrm{H}^{+}$. The simulated cation to proton activity ratios also show a systematic decrease with temperature. This overall trend can be explained by an increase in the ionization of pure water and by the increase in acidity of heated seawater alone, as shown for $\mathrm{pH}$ in Figure 3.

The excellent agreement between the simulations and the natural Icelandic waters up to temperatures of $300^{\circ} \mathrm{C}$ (Figure 4) provides confidence in the capacity of the model to estimate the processes affecting the fluid chemistry of natural open systems. This reinforces previous findings, 
which indicate that fluid/rock interaction may approach equilibrium conditions in geothermal systems, where the fluid chemistry is controlled by the equilibrium of the fluids with primary and secondary minerals $[63,85,119]$. Furthermore, the major element chemistry in these systems can be predicted by thermodynamic modeling down to a temperature of $\sim 50^{\circ} \mathrm{C}$, where kinetic factors begin to have a dominant control on the alteration mineralogy and water chemistry $[63,85,120]$.

4.4. The Role of Fluid/Rock Ratios for Basalt Alteration at Mid-Ocean Ridges. The F/R ratio effective during hydrothermal alteration at mid-ocean ridges has an important control on both the mineralogy of the altered basalt (Figure 2) and the chemistry of the vent fluids (Figures 3 and 4), confirming previous results by Mottl and Seyfried [11] and Reed [12]. Two end-member scenarios can be distinguished based on the present simulations, corresponding to a rock-dominated and seawater-dominated seafloor hydrothermal system, respectively.

Rock-buffered conditions (F/R of 1 to 50) are characterized by relatively high values of $a \mathrm{Ca}^{2+} /\left(a \mathrm{H}^{+}\right)^{2}$ and $a \mathrm{Na}^{+} /$ $a \mathrm{H}^{+}$. These high cation to proton activity ratios can be directly related to the primary mineralogy of mid-ocean ridge basalts, which includes plagioclase and diopside. At these conditions, the fluid/rock interaction chemistry is dominated by the composition of the fresh rock and the effect of seawater is largely catalytic $[85,86]$. High $\mathrm{Ca}^{2+}$ and $\mathrm{Na}^{+}$activities at rock-buffered conditions favor the formation of alteration assemblages including calcite and zeolites (scolecite, natrolite, thomsonite, and analcime) at low temperature, while epidote, prehnite, albite, wairakite, and clinozoisite are predicted to form at high temperature (Figure 2). The high variations in total dissolved $\mathrm{Ca}, \mathrm{Na}$, and $\mathrm{K}$ at low $\mathrm{F} / \mathrm{R}$ ratios (Figure 3) can be related to extensive fluid/mineral interaction, characterized by numerous secondary mineral phases buffering the fluid composition. The concentrations of total dissolved $\mathrm{Ca}$ at low $\mathrm{F} / \mathrm{R}$ ratios in the model are higher than those at high $\mathrm{F} / \mathrm{R}$ ratios for most of the temperature range covered, as supported by similar results from experimental work of Hajash and Chandler [121]. In contrast, the total dissolved $\mathrm{Mg}$ concentration was negligible at rock-buffered conditions, with the lowest values $<10^{-1} \mathrm{mmol} / \mathrm{kg}$ obtained at $\mathrm{F} / \mathrm{R}$ between 1 and 20 . These low $\mathrm{Mg}$ concentrations are explained by the near complete uptake of seawater-derived $\mathrm{Mg}^{2+}$ and $\mathrm{OH}^{-}$to form smectites and chlorite. The excess $\mathrm{H}^{+}$is consumed by hydrolysis reactions of silicate minerals [11]. Fluid/rock interaction at rock-buffered conditions is characterized by alkaline conditions, in agreement with simulated $\mathrm{pH}$ values ranging from 7 to 11 . Redox reactions are also taking place between the reduced basaltic rocks and oxidized seawater, causing a sharp drop of the redox potential at rock-buffered conditions with Eh values ranging between -0.2 and $-0.6 \mathrm{~V}$. These reduced conditions correspond to the maximum stability of pyrite and the precipitation of pyrrhotite, resulting from the buffering of seawater sulfate by sulfide minerals.

Seawater-buffered conditions occur at high F/R ratios ( $\mathrm{F} / \mathrm{R}$ of 50 to 100$)$ and are characterized by relatively high values of $a \mathrm{Mg}^{2+} /\left(a \mathrm{H}^{+}\right)^{2}$ and a low $\mathrm{pH}$. At these conditions, seawater components gain increasingly in importance relative to rock components and are very effective at buffering the system to lower $\mathrm{pH}$ values (Figure 3 ). This can be related to the production of excess $\mathrm{H}^{+}$over $\mathrm{OH}^{-}$associated to the precipitation of $\mathrm{Mg}^{2+}$ and $\mathrm{OH}^{-}$from the solution into a magnesium hydroxide sulfate hydrate upon heating of seawater [5]. The same mechanism occurs during the alteration of basalts with the formation of Mg-bearing hydrated minerals, where $\mathrm{Mg}^{2+}$ and $\mathrm{OH}^{-}$are taken up by smectites and chlorite [11]. While the excess of $\mathrm{H}^{+}$produced by seawater at rock-buffered conditions is consumed by the alteration minerals, the production of $\mathrm{H}^{+}$at fluid-buffered conditions exceeds that of $\mathrm{H}^{+}$consumption and the $\mathrm{pH}$ is lowered. The low $\mathrm{pH}$ values present at seawater-dominated conditions also have a direct influence on the alteration mineralogy. High $\mathrm{H}^{+}$activities favor the dissolution of rock components and the precipitation of Al-Si-rich minerals such as kaolinite at low temperature. The total dissolved Mg concentrations at seawater-buffered conditions attain values several orders of magnitude higher than in the rock-buffered environment (Figure 3); an observation also made in experimental studies of Hajash and Chandler [121]. The large volumes of reacted seawater involved in the system preserved near-maximal concentrations of $\mathrm{Mg}$ while large quantities of smectites and chlorite were precipitated (Figures 2 and 3), indicating that the amount of $\mathrm{Mg}$ available from the fluid is magnitudes higher to what can be buffered by the rock and precipitated into the $\mathrm{Mg}$-bearing alteration assemblage. The precipitation of significant quantities of talc at relatively high $\mathrm{F} / \mathrm{R}$ values of 50 and 70 can further be explained by the high concentrations of $\mathrm{Mg}$ in the fluid at these conditions. The progressive decrease of $a \mathrm{Ca}^{2+} /\left(a \mathrm{H}^{+}\right)^{2}$ towards increasingly seawaterbuffered conditions results from the precipitation of $\mathrm{Ca}$ with seawater sulfate into anhydrite. Anhydrite in mid-ocean ridge hydrothermal systems is characterized by isotopic ${ }^{34} \mathrm{~S}$ values identical to those measured in seawater sulfate $[112,122]$, validating the importance of seawater as a source of available sulfur to form this mineral. The circulation of more oxidized seawater in the reduced basaltic rocks at high $\mathrm{F} / \mathrm{R}$ ratios generates a relatively more oxidized alteration assemblage than at rock-buffered conditions, as illustrated by a redox potential ranging between -0.25 and $0 \mathrm{~V}$ (Figure 3). These more oxidized conditions are in agreement with the maximum stability of hematite.

\subsection{Fluid Chemistry of Mid-Ocean Ridge Hydrothermal} Vents. A compilation of 123 fluid compositions collected from submarine hydrothermal vents in various mid-ocean ridge settings (Cayman Spreading Center, Central Indian Ridge, East Pacific Rise, and Mid-Atlantic Ridge) and analogous submarine basalt-dominated environments (East Scotia Ridge, New Hebrides, and Western Manus Basin) is provided in Table 2. Natural vent fluid compositions are compared to the simulated fluid compositions for $\mathrm{Mg}, \mathrm{Ca}, \mathrm{Na}$, and $\mathrm{K}$ in Figure 5. Vent concentrations in $\mathrm{Mg}$ present an excellent agreement with the model at all temperatures, while vent concentrations in Ca present a poor agreement at low temperature and an excellent agreement at higher temperature, 
TABLe 2: Compilation of major element compositions of fluids from selected basalt-hosted seafloor hydrothermal vents.

\begin{tabular}{|c|c|c|c|c|c|c|c|c|c|}
\hline Tectonic setting location/vent & $\begin{array}{l}\text { Depth } \\
(\mathrm{m})\end{array}$ & $\begin{array}{l}T_{\max } \\
\left({ }^{\circ} \mathrm{C}\right)\end{array}$ & $\begin{array}{c}\mathrm{pH} \\
\left(25^{\circ} \mathrm{C}\right) \\
\end{array}$ & $\begin{array}{c}\mathrm{Mg}^{\mathrm{a}} \\
(\mathrm{mmol} / \mathrm{kg}) \\
\end{array}$ & $\begin{array}{c}\mathrm{Ca}^{\mathrm{b}} \\
(\mathrm{mmol} / \mathrm{kg})\end{array}$ & $\begin{array}{c}\mathrm{Na}^{\mathrm{b}} \\
(\mathrm{mmol} / \mathrm{kg})\end{array}$ & $\begin{array}{c}\mathrm{K}^{\mathrm{b}} \\
(\mathrm{mmol} / \mathrm{kg})\end{array}$ & $\begin{array}{c}\mathrm{Cl}^{\mathrm{b}} \\
(\mathrm{mmol} / \mathrm{kg})\end{array}$ & Reference \\
\hline \multicolumn{10}{|l|}{ Mid-ocean ridges } \\
\hline \multicolumn{10}{|l|}{ Cayman Spreading Center } \\
\hline Von Damm vent field & 2280 & 215 & 6.0 & 14.7 & 15.0 & 555 & 15.5 & 643 & {$[1]$} \\
\hline Von Damm vent field & 2280 & 215 & 6.2 & 31.4 & 13.4 & 513 & 13.1 & 592 & {$[1]$} \\
\hline Von Damm vent field & 2307 & 138 & 6.2 & 27.3 & 12.9 & 531 & 14.1 & 610 & {$[1]$} \\
\hline Von Damm vent field & 2308 & 138 & 6.1 & 26.3 & 13.1 & 534 & 14.1 & 599 & {$[1]$} \\
\hline Von Damm vent field & 2308 & 138 & 6.2 & 29.5 & 13.2 & 536 & 13.9 & 603 & {$[1]$} \\
\hline Von Damm vent field & 2379 & 108 & 6.2 & 22.7 & 13.4 & 519 & 13.6 & 601 & {$[1]$} \\
\hline Von Damm vent field & 2379 & 108 & 7.0 & 40.6 & 11.6 & 480 & 11.4 & 574 & {$[1]$} \\
\hline \multicolumn{10}{|l|}{ Central Indian Ridge } \\
\hline $23-25^{\circ}$ S CIR, Kairei vent field & 2422 & 315 & 3.4 & 9.3 & 28.6 & 492 & 13.3 & 571 & {$[2]$} \\
\hline $23-25^{\circ} \mathrm{S}$ CIR, Kairei vent field & 2448 & 349 & 3.5 & 5.8 & 30.2 & 511 & 14.5 & 595 & {$[2]$} \\
\hline $23-25^{\circ} \mathrm{S}$ CIR, Kairei vent field & 2452 & 365 & 3.4 & 1.1 & 31.3 & 528 & 15.2 & 620 & {$[2]$} \\
\hline $23-25^{\circ} \mathrm{S}$ CIR, Edmond vent field & 3281 & 382 & 3.0 & 1.7 & 58.1 & 698 & 44.7 & 929 & {$[2]$} \\
\hline $23-25^{\circ} \mathrm{S}$ CIR, Edmond vent field & 3300 & 273 & 3.0 & 19.1 & 64.9 & 718 & 45.4 & 926 & {$[2]$} \\
\hline $23-25^{\circ} \mathrm{S}$ CIR, Edmond vent field & 3303 & 293 & 3.1 & 13.2 & 64.1 & 733 & 44.6 & 933 & {$[2]$} \\
\hline $23-25^{\circ} \mathrm{S}$ CIR, Edmond vent field & 3273 & 370 & 3.1 & 3.0 & 63.4 & 721 & 44.2 & 927 & {$[2]$} \\
\hline $\begin{array}{l}\text { Rodriguez Triple Junction, } \\
\text { Kairei }\end{array}$ & 2450 & 360 & 5.2 & 31.0 & 22.0 & 531 & 11.7 & 587 & {$[3]$} \\
\hline $\begin{array}{l}\text { Rodriguez Triple Junction, } \\
\text { Kairei }\end{array}$ & 2450 & 360 & 3.8 & 2.5 & 29.7 & 567 & 14.6 & 634 & {$[3]$} \\
\hline $\begin{array}{l}\text { Rodriguez Triple Junction, } \\
\text { Kairei }\end{array}$ & 2450 & 360 & 3.4 & 1.3 & 28.7 & 550 & 14.1 & 645 & {$[3]$} \\
\hline \multicolumn{10}{|l|}{ East Pacific Rise } \\
\hline 9-10 N EPR, Q.1 & 2513 & 371 & 2.8 & 6.9 & 0.8 & 58 & 1.6 & 71 & {$[4]$} \\
\hline $9-10^{\circ} \mathrm{N}$ EPR, G.1 & 2523 & 326 & 2.1 & 10.5 & 1.5 & 130 & 2.9 & 150 & {$[4]$} \\
\hline $9-10^{\circ} \mathrm{N}$ EPR, G.2 & 2550 & 355 & 3.7 & 23.1 & 0.2 & 134 & 1.9 & 154 & {$[4]$} \\
\hline $9-10^{\circ} \mathrm{N}$ EPR, B9.1 & 2521 & 368 & 2.6 & 4.0 & 2.1 & 137 & 3.7 & 154 & {$[4]$} \\
\hline $9-10^{\circ} \mathrm{N}$ EPR, P.1 & 2524 & 369 & 2.6 & 9.1 & 1.2 & 110 & 2.4 & 135 & {$[4]$} \\
\hline $9-10^{\circ} \mathrm{N}$ EPR, P.2 & 2550 & 386 & 4.2 & 42.5 & 6.9 & 166 & -0.9 & 178 & {$[4]$} \\
\hline $9-10^{\circ} \mathrm{N}$ EPR, V.1 & 2525 & 78 & 5.5 & 44.1 & 4.9 & 224 & 3.4 & 262 & {$[4]$} \\
\hline 9-10 N EPR, T.1 & 2529 & 112 & 5.4 & 43.5 & 0.0 & 313 & 9.5 & 339 & {$[4]$} \\
\hline $9-10^{\circ} \mathrm{N}$ EPR, Aa.1 & 2533 & 390 & 2.8 & 7.9 & 2.0 & 70 & 2.2 & 81 & {$[4]$} \\
\hline $9-10^{\circ} \mathrm{N}$ EPR, Aa.2 & 2550 & 396 & 2.5 & 8.6 & 1.5 & 25 & 0.6 & 31 & {$[4]$} \\
\hline $9-10^{\circ} \mathrm{N}$ EPR, Aa.3 & 2550 & 403 & 2.5 & 18.4 & 1.1 & 31 & 0.2 & 43 & {$[4]$} \\
\hline $9-10^{\circ} \mathrm{N}$ EPR, L.1 & 2542 & 388 & 3.1 & 34.2 & 2.2 & 94 & 2.8 & 114 & {$[4]$} \\
\hline $9-10^{\circ} \mathrm{N}$ EPR, H.1 & 2557 & 313 & 5.0 & 30.6 & 7.1 & 333 & 15.0 & 371 & {$[4]$} \\
\hline $9-10^{\circ} \mathrm{N}$ EPR, B.1 & 2562 & 329 & 3.2 & 3.7 & 17.1 & 359 & 12.9 & 416 & {$[4]$} \\
\hline $9-10^{\circ} \mathrm{N}$ EPR, C. 1 & 2572 & 345 & 3.3 & 3.7 & 11.9 & 287 & 9.5 & 329 & {$[4]$} \\
\hline 9-10 N EPR, R.1 & 2543 & 123 & 3.0 & 30.0 & 51.4 & 674 & 34.2 & 826 & {$[4]$} \\
\hline $9-10^{\circ} \mathrm{N}$ EPR, D.1 & 2574 & 290 & 3.2 & 4.1 & 45.5 & 733 & 41.8 & 846 & {$[4]$} \\
\hline $9-10^{\circ} \mathrm{N}$ EPR, D.2 & 2550 & 308 & 3.1 & 2.1 & 41.8 & 670 & 40.8 & 801 & {$[4]$} \\
\hline 9-10 N EPR, E.1 & 2565 & 280 & 3.6 & 20.0 & 46.9 & 707 & 41.3 & 859 & {$[4]$} \\
\hline $9-10^{\circ} \mathrm{N}$ EPR, E.2 & 2550 & 274 & 3.1 & 9.2 & 41.8 & 701 & 41.3 & 841 & {$[4]$} \\
\hline $9-10^{\circ} \mathrm{N}$ EPR, K.1 & 2577 & 263 & 5.7 & 38.5 & 23.0 & 465 & 27.8 & 556 & {$[4]$} \\
\hline $9-10^{\circ} \mathrm{N}$ EPR, F.1 & 2585 & 388 & 2.8 & 5.5 & 1.3 & 33 & 1.2 & 46 & {$[4]$} \\
\hline $21^{\circ} 33.5^{\prime}-21^{\circ} 34^{\prime} \mathrm{S}$ EPR, Brandon & 2834 & 404 & 3.2 & 1.0 & 17.5 & 267 & 7.5 & 317 & {$[5]$} \\
\hline $21^{\circ} 33.5^{\prime}-21^{\circ} 34^{\prime} \mathrm{S}$ EPR, Brandon & 2834 & 405 & 3.7 & 3.7 & 20.6 & 303 & 9.1 & 338 & {$[5]$} \\
\hline
\end{tabular}


TABle 2: Continued.

\begin{tabular}{|c|c|c|c|c|c|c|c|c|c|}
\hline Tectonic setting location/vent & $\begin{array}{c}\text { Depth } \\
(\mathrm{m})\end{array}$ & $\begin{array}{l}T_{\max } \\
\left({ }^{\circ} \mathrm{C}\right)\end{array}$ & $\begin{array}{c}\mathrm{pH} \\
\left(25^{\circ} \mathrm{C}\right)\end{array}$ & $\begin{array}{c}\mathrm{Mg}^{\mathrm{a}} \\
(\mathrm{mmol} / \mathrm{kg})\end{array}$ & $\begin{array}{c}\mathrm{Ca}^{\mathrm{b}} \\
(\mathrm{mmol} / \mathrm{kg})\end{array}$ & $\begin{array}{c}\mathrm{Na}^{\mathrm{b}} \\
(\mathrm{mmol} / \mathrm{kg})\end{array}$ & $\begin{array}{c}\mathrm{K}^{\mathrm{b}} \\
(\mathrm{mmol} / \mathrm{kg})\end{array}$ & $\begin{array}{c}\mathrm{Cl}^{\mathrm{b}} \\
(\mathrm{mmol} / \mathrm{kg})\end{array}$ & Reference \\
\hline $21^{\circ} 33.5^{\prime}-21^{\circ} 34^{\prime} \mathrm{S}$ EPR, Brandon & 2834 & 401 & 3.1 & 2.1 & 18.4 & 266 & 8.2 & 339 & {$[5]$} \\
\hline $21^{\circ} 33.5^{\prime}-21^{\circ} 34^{\prime} \mathrm{S}$ EPR, Brandon & 2834 & 400 & 5.1 & 24.8 & 20.3 & 244 & 8.2 & 330 & {$[5]$} \\
\hline $21^{\circ} 33.5^{\prime}-21^{\circ} 34^{\prime}$ S EPR, Brandon & 2834 & 403 & 3.2 & 3.1 & 16.3 & 251 & 7.3 & 304 & [5] \\
\hline $21^{\circ} 33.5^{\prime}-21^{\circ} 34^{\prime} \mathrm{S}$ EPR, Brandon & 2834 & 401 & 3.1 & 1.3 & 15.8 & 242 & 6.9 & 297 & {$[5]$} \\
\hline $21^{\circ} 33.5^{\prime}-21^{\circ} 34^{\prime}$ S EPR, Brandon & 2834 & 405 & 4.0 & 10.0 & 21.3 & 270 & 7.7 & 330 & [5] \\
\hline $21^{\circ} 33.5^{\prime}-21^{\circ} 34^{\prime} \mathrm{S}$ EPR, Brandon & 2834 & 368 & 3.2 & 5.4 & 34.0 & 449 & 13.4 & 558 & {$[5]$} \\
\hline $21^{\circ} 33.5^{\prime}-21^{\circ} 34^{\prime} \mathrm{S}$ EPR, Brandon & 2834 & 376 & 3.3 & 7.1 & 32.8 & 441 & 13.8 & 557 & {$[5]$} \\
\hline $17-19^{\circ} \mathrm{S}$ EPR, Tanio & 2576 & 50 & 7.6 & 49.0 & 10.3 & 465 & 9.8 & 546 & {$[6]$} \\
\hline $17-19^{\circ} \mathrm{S}$ EPR, Nadir & 2574 & 340 & 3.1 & 3.3 & 5.5 & 146 & 6.9 & 212 & {$[6]$} \\
\hline 17-195 EPR, Rehu-Marka & 2573 & 320 & 7.4 & 46.3 & 10.5 & 462 & 9.6 & 544 & {$[6]$} \\
\hline $17-19^{\circ} \mathrm{S}$ EPR, Rehu-Marka & 2573 & 320 & 3.8 & 39.2 & 11.9 & 409 & 10.5 & 491 & {$[6]$} \\
\hline $17-19^{\circ} \mathrm{S}$ EPR, Rehu-Marka & 2573 & 260 & 7.5 & 47.6 & 10.6 & 464 & 10.2 & 539 & {$[6]$} \\
\hline $17-19^{\circ} \mathrm{S}$ EPR, Rehu-Marka & 2573 & 260 & 7.3 & 47.6 & 10.5 & 444 & 9.9 & 540 & {$[6]$} \\
\hline 17-195 EPR, Stockwork & 2630 & 210 & 3.2 & 4.9 & 8.4 & 255 & 6.4 & 283 & {$[6]$} \\
\hline $17-19^{\circ} \mathrm{S}$ EPR, Fromveur & 2621 & 310 & 3.1 & 13.1 & 7.2 & 220 & 4.7 & 251 & {$[6]$} \\
\hline $17-19^{\circ} \mathrm{S}$ EPR, Diffuse flow & 2647 & 150 & 7.6 & 51.8 & 10.2 & 479 & 10.2 & 563 & {$[6]$} \\
\hline 17-195 EPR, Fromveur & 2620 & 310 & 4.8 & 41.1 & 9.6 & 392 & 8.5 & 457 & {$[6]$} \\
\hline $17-19^{\circ} \mathrm{S}$ EPR, Tchao & 2659 & 210 & 7.8 & 48.3 & 11.3 & 474 & 10.9 & 573 & {$[6]$} \\
\hline $17-19^{\circ} \mathrm{S}$ EPR, Akorta & 2669 & 305 & 3.4 & 4.9 & 43.6 & 659 & 19.4 & 821 & {$[6]$} \\
\hline $17-19^{\circ} \mathrm{S}$ EPR, Akorta & 2669 & 300 & 3.3 & 6.6 & 43.1 & 657 & 19.4 & 830 & {$[6]$} \\
\hline 17-19S EPR, Rehu-Marka & 2573 & 300 & 3.6 & 16.0 & 11.7 & 345 & 12.0 & 390 & {$[6]$} \\
\hline 17-19S EPR, Rehu-Marka & 2573 & 305 & 7.2 & 49.6 & 11.2 & 480 & 10.5 & 538 & {$[6]$} \\
\hline 17-19º EPR, Kihi & 2575 & 60 & 4.8 & 48.9 & 11.1 & 468 & 10.5 & 534 & {$[6]$} \\
\hline \multicolumn{10}{|l|}{ Mid-Atlantic Ridge } \\
\hline Lucky Strike, Statue of Liberty & 1630 & 202 & 4.2 & 10.3 & 34.3 & 483 & 24.4 & - & {$[7]$} \\
\hline Lucky Strike, Sintra & 1618 & 212 & 4.9 & 11.4 & 37.3 & 469 & 24.3 & - & {$[7]$} \\
\hline Lucky Strike, Eiffel Tower & 1687 & 325 & 4.1 & 3.4 & 29.8 & 386 & 20.7 & - & {$[7]$} \\
\hline Lucky Strike, Marker 4 & 1700 & 297 & 4.1 & 3.9 & 30.0 & 385 & 20.6 & - & [7] \\
\hline Lucky Strike, Marker 6 & 1703 & 303 & 4.1 & 4.9 & 30.8 & 406 & 20.4 & - & {$[7]$} \\
\hline Lucky Strike, Marker 7 & 1708 & 302 & 4.0 & 2.2 & 29.8 & 382 & 20.5 & - & {$[7]$} \\
\hline Lucky Strike, 2607 vent & 1706 & 319 & 4.5 & 10.8 & 30.0 & 382 & 20.7 & - & {$[7]$} \\
\hline Lucky Strike, Sintra & 1618 & 222 & 4.3 & 4.4 & 42.1 & 401 & 27.2 & - & {$[7]$} \\
\hline Lucky Strike, Eiffel Tower & 1687 & 323 & 4.3 & 2.3 & 33.0 & 346 & 22.2 & - & [7] \\
\hline Lucky Strike, Marker 4 & 1700 & 318 & 3.9 & 1.9 & 33.4 & 339 & 22.7 & - & {$[7]$} \\
\hline Lucky Strike, 2608 vent & 1719 & 308 & 3.8 & 3.0 & 42.1 & 406 & 27.4 & - & {$[7]$} \\
\hline Lucky Strike, Jason & 1644 & 308 & 3.9 & 7.3 & 41.7 & 420 & 27.6 & - & {$[7]$} \\
\hline Lucky Strike, Crystal & 1726 & 281 & 4.2 & 2.2 & 35.3 & 470 & 28.8 & - & {$[7]$} \\
\hline \multicolumn{10}{|l|}{ Back-arc basins } \\
\hline \multicolumn{10}{|l|}{ East Scotia Ridge } \\
\hline E2 dog's head chimney & 2600 & 323 & 3.0 & 2.1 & 29.9 & 429 & 38.0 & 542 & {$[8]$} \\
\hline E2 dog's head chimney & 2600 & 323 & 3.0 & 2.3 & 30.1 & 431 & 38.0 & 540 & {$[8]$} \\
\hline E2 dog's head chimney & 2600 & 351 & 3.1 & 1.0 & 30.0 & 427 & 38.8 & 528 & {$[8]$} \\
\hline E2 sepia chimney & 2600 & 351 & 3.7 & 12.1 & 26.7 & 429 & 31.8 & 534 & {$[8]$} \\
\hline E2 sepia chimney & 2600 & 351 & 3.1 & 2.3 & 30.6 & 420 & 37.1 & 535 & {$[8]$} \\
\hline E2 sepia chimney & 2600 & 353 & 3.1 & 1.9 & 30.9 & 421 & 37.1 & 531 & {$[8]$} \\
\hline E2 sepia chimney & 2600 & 353 & 3.1 & 2.0 & 31.0 & 423 & 37.1 & 528 & {$[8]$} \\
\hline E2 sepia chimney & 2600 & 347 & 3.1 & 1.6 & 31.1 & 418 & 37.0 & 535 & {$[8]$} \\
\hline
\end{tabular}


TABLE 2: Continued.

\begin{tabular}{|c|c|c|c|c|c|c|c|c|c|}
\hline Tectonic setting location/vent & $\begin{array}{c}\text { Depth } \\
(\mathrm{m})\end{array}$ & $\begin{array}{l}T_{\max } \\
\left({ }^{\circ} \mathrm{C}\right) \\
\end{array}$ & $\begin{array}{c}\mathrm{pH} \\
\left(25^{\circ} \mathrm{C}\right) \\
\end{array}$ & $\begin{array}{c}\mathrm{Mg}^{\mathrm{a}} \\
(\mathrm{mmol} / \mathrm{kg})\end{array}$ & $\begin{array}{c}\mathrm{Ca}^{\mathrm{b}} \\
(\mathrm{mmol} / \mathrm{kg})\end{array}$ & $\begin{array}{c}\mathrm{Na}^{\mathrm{b}} \\
(\mathrm{mmol} / \mathrm{kg})\end{array}$ & $\begin{array}{c}\mathrm{K}^{\mathrm{b}} \\
(\mathrm{mmol} / \mathrm{kg})\end{array}$ & $\begin{array}{c}\mathrm{Cl}^{\mathrm{b}} \\
(\mathrm{mmol} / \mathrm{kg})\end{array}$ & Reference \\
\hline E2 sepia chimney & 2600 & 347 & 3.1 & 1.6 & 30.9 & 419 & 37.3 & 532 & {$[8]$} \\
\hline E2 sepia flange & 2600 & 313 & 2.9 & 4.0 & 28.2 & 413 & 34.9 & 521 & {$[8]$} \\
\hline E2 sepia flange & 2600 & 313 & 2.9 & 4.2 & 28.1 & 414 & 35.0 & 516 & {$[8]$} \\
\hline E2 diffuse flow & 2600 & 20 & 6.4 & 49.9 & 11.0 & 458 & 11.0 & 541 & {$[8]$} \\
\hline E2 diffuse flow & 2600 & 20 & 6.4 & 50.1 & 11.0 & 459 & 10.9 & 540 & {$[8]$} \\
\hline E2 diffuse flow & 2600 & 4 & 7.6 & 52.6 & 10.2 & 464 & 10.0 & 542 & {$[8]$} \\
\hline E2 diffuse flow & 2600 & 4 & 7.6 & 52.7 & 10.2 & 464 & 10.0 & 531 & {$[8]$} \\
\hline E2 diffuse flow & 2600 & 8 & 6.8 & 51.7 & 10.4 & 463 & 10.4 & 535 & {$[8]$} \\
\hline E2 diffuse flow & 2600 & 8 & 6.9 & 51.8 & 10.5 & 464 & 10.4 & 540 & {$[8]$} \\
\hline E9 black and white chimney & 2400 & 380 & 3.4 & 8.0 & 4.7 & 152 & 4.7 & 163 & {$[8]$} \\
\hline E9 black and white chimney & 2400 & 380 & 3.5 & 0.6 & 5.5 & 99 & 5.5 & 106 & {$[8]$} \\
\hline E9 black and white chimney & 2400 & 383 & 3.8 & 8.4 & 11.6 & 156 & 11.6 & 166 & {$[8]$} \\
\hline E9 black and white chimney & 2400 & 383 & 3.4 & 2.4 & 6.1 & 111 & 6.1 & 124 & {$[8]$} \\
\hline E9 black and white chimney & 2400 & 357 & 3.7 & 15.8 & 7.8 & 205 & 7.8 & 227 & {$[8]$} \\
\hline E9 black and white chimney & 2400 & 357 & 3.8 & 14.4 & 7.8 & 195 & 7.8 & 214 & {$[8]$} \\
\hline E9 carwash diffuse flow & 2400 & 11 & 6.0 & 52.0 & 9.9 & 458 & 9.8 & 539 & {$[8]$} \\
\hline E9 carwash diffuse flow & 2400 & 11 & 6.0 & 51.5 & 9.8 & 452 & 9.7 & 530 & {$[8]$} \\
\hline E9 ivory tower chimney & 2400 & 348 & 3.1 & 2.0 & 5.8 & 201 & 14.7 & 227 & {$[8]$} \\
\hline E9 ivory tower chimney & 2400 & 348 & 3.2 & 3.2 & 6.1 & 207 & 14.6 & 240 & {$[8]$} \\
\hline E9 pagoda chimney & 2400 & 351 & 3.4 & 0.8 & 6.4 & 196 & 14.8 & 227 & {$[8]$} \\
\hline E9 pagoda chimney & 2400 & 351 & 3.4 & 2.3 & 6.4 & 202 & 14.5 & 234 & {$[8]$} \\
\hline E9 launch pad chimney & 2400 & 351 & 3.2 & 4.5 & 6.1 & 188 & 12.2 & 211 & {$[8]$} \\
\hline E9 launch pad chimney & 2400 & 351 & 3.6 & 12.9 & 6.7 & 237 & 11.8 & 264 & {$[8]$} \\
\hline E9 S field diffuse flow & 2400 & 5 & 7.3 & 52.8 & 10.0 & 461 & 9.9 & 535 & {$[8]$} \\
\hline E9 S field diffuse flow & 2400 & 5 & 7.4 & 52.7 & 10.0 & 462 & 9.8 & 529 & {$[8]$} \\
\hline E9 S field diffuse flow & 2400 & 20 & 5.9 & 50.2 & 10.0 & 451 & 9.9 & 520 & {$[8]$} \\
\hline E9 S field diffuse flow & 2400 & 20 & 6.0 & 50.5 & 10.1 & 455 & 9.9 & 527 & {$[8]$} \\
\hline \multicolumn{10}{|l|}{ New Hebrides } \\
\hline Nifonea vent field & 1862 & 250 & 3.3 & 12.3 & 10.1 & 141 & 3.1 & 173 & [9] \\
\hline Nifonea vent field & 1862 & 107 & 4.4 & 27.6 & 9.9 & 267 & 5.8 & 311 & [9] \\
\hline Nifonea vent field & 1862 & 345 & 4.7 & 25.4 & 9.6 & 257 & 5.8 & 296 & [9] \\
\hline Nifonea vent field & 1862 & 368 & 2.9 & 14.9 & 28.2 & 255 & 6.3 & 340 & [9] \\
\hline Nifonea vent field & 1862 & 368 & 3.4 & 3.8 & 5.7 & 53 & 1.1 & 63 & {$[9]$} \\
\hline \multicolumn{10}{|l|}{ Western Manus Basin } \\
\hline Vienna Woods & 2470 & 282 & 4.8 & 3.4 & 76.6 & 520 & 20.6 & 694 & {$[10]$} \\
\hline Vienna Woods & 2470 & 282 & 4.4 & 1.6 & 78.1 & 510 & 21.0 & 683 & {$[10]$} \\
\hline Vienna Woods & 2470 & 282 & 4.9 & 1.4 & 77.3 & 506 & 20.7 & 677 & {$[10]$} \\
\hline Vienna Woods & 2470 & 273 & 4.2 & 1.0 & 79.5 & 509 & 21.0 & 687 & {$[10]$} \\
\hline Vienna Woods & 2470 & 285 & 4.7 & 1.1 & 69.5 & 504 & 20.0 & 663 & {$[10]$} \\
\hline Vienna Woods & 2470 & 285 & 5.4 & 14.9 & 53.5 & 494 & 17.2 & 644 & {$[10]$} \\
\hline
\end{tabular}

${ }^{\mathrm{a}} \mathrm{Mg}$ concentrations correspond to the minimum value obtained during sampling or "minimum $\mathrm{Mg}$." ${ }^{\mathrm{b}} \mathrm{Ca}, \mathrm{Na}, \mathrm{K}$, and $\mathrm{Cl}$ concentrations correspond to the "endmember" value, extrapolated to $\mathrm{Mg}=0 \mathrm{mmol} / \mathrm{kg}$. Vent data: ${ }^{1}$ Hodgkinson et al. [50], ${ }^{2}$ Gallant and Von Damm [124], ${ }^{3} \mathrm{Gamo}$ et al. [125], ${ }^{4} \mathrm{Von}$ Damm [126], ${ }^{5}$ Von Damm et al. [19], ${ }^{6}$ Charlou et al. [127], ${ }^{7}$ Von Damm et al. [128], ${ }^{8}$ James et al. [20], ${ }^{9}$ Schmidt et al. [129], and ${ }^{10}$ Reeves et al. [130].

except above $\sim 300^{\circ} \mathrm{C}$. Both the vent concentrations in $\mathrm{Na}$ and $\mathrm{K}$ present an excellent agreement at all temperatures, except above $\sim 300^{\circ} \mathrm{C}$. Since natural hydrothermal fluids have been sampled from active vents on the seafloor, their compositions may not only reflect the result of fluid/rock interaction processes in the reaction zone alone, but of a combination of these processes with processes related to their subsequent rise along the volcanic structures towards the seafloor environment. Kelley et al. [123] noted that submarine hydrothermal fluids showed relative enrichments and depletions of $\mathrm{NaCl}$ with respect to seawater and suggested that these variations may represent phase separation processes 

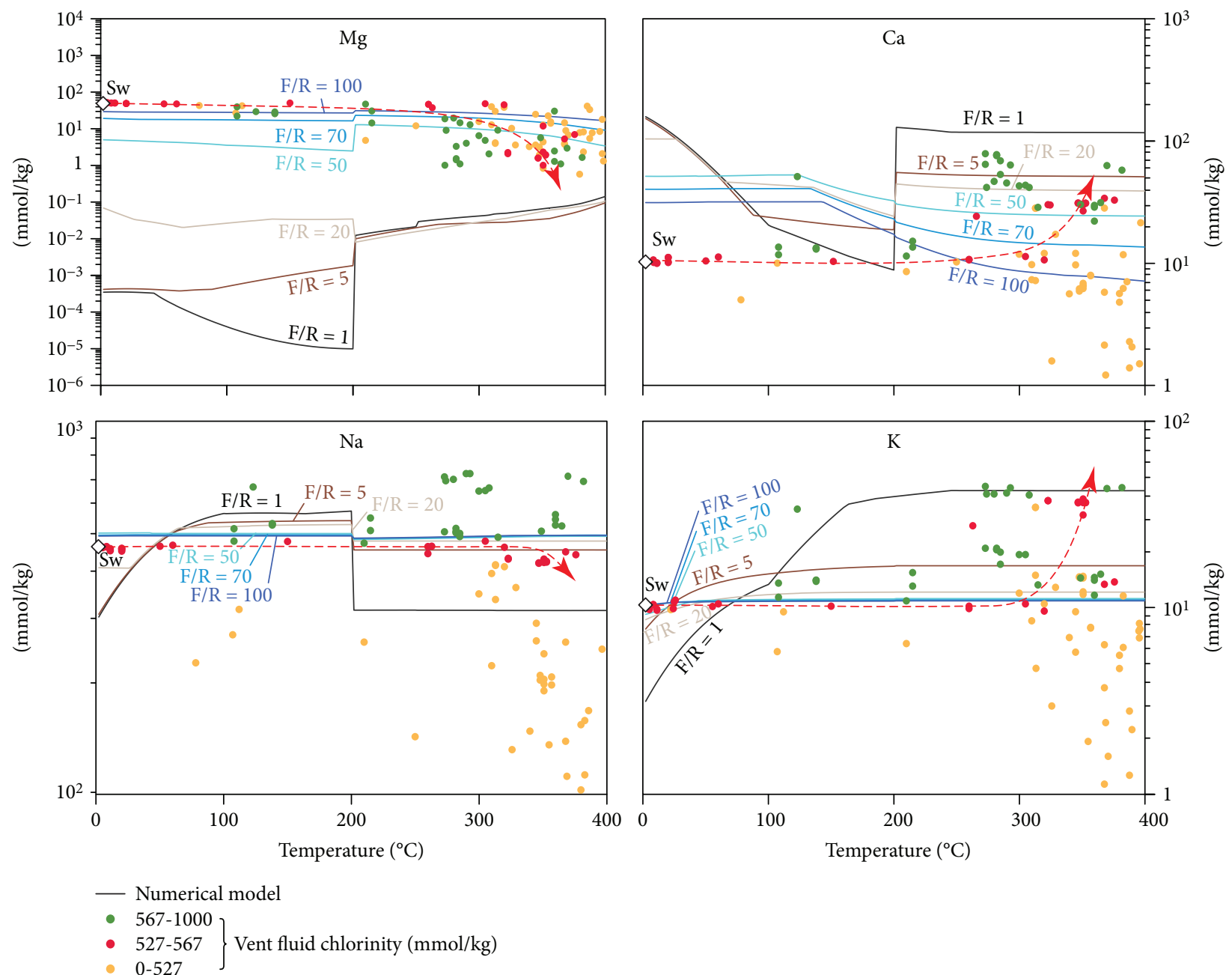

FIGURE 5: Comparison between the simulated fluid compositions (lines) and natural vent compositions at mid-ocean ridges and analogous submarine basalt-dominated environments (dots) for the total dissolved cation compositions of $\mathrm{Mg}$, $\mathrm{Ca}$, $\mathrm{Na}$, and $\mathrm{K}$. The natural vent compositions are sorted with respect to their associated chlorinities. Vent geochemical data are provided in Table 2. Orange dots represent a $\mathrm{Cl}$ value of $0-527 \mathrm{mmol} / \mathrm{kg}$, red dots represent a $\mathrm{Cl}$ value of $527-567 \mathrm{mmol} / \mathrm{kg}$, and green dots represent a $\mathrm{Cl}$ value of $567-1000 \mathrm{mmol} /$ $\mathrm{kg}$. Dashed red arrows show the trends of natural fluid samples with a chlorinity corresponding to the value of seawater at $2^{\circ} \mathrm{C}$ $\left(\mathrm{Cl}_{\mathrm{Sw}, 2^{\circ} \mathrm{C}}=546.7 \mathrm{mmol} / \mathrm{kg} \pm 20 \mathrm{mmol} / \mathrm{kg}\right)$. White diamonds represent the composition of seawater at $2^{\circ} \mathrm{C}$. The seawater-basalt simulations were carried out from 2 to $400^{\circ} \mathrm{C}, 500$ bars, and variable fluid/rock (F/R) mass ratios.

of hydrothermal fluids enriched in $\mathrm{NaCl}$. The fluid compositions selected in our vent data compilation also present a wide range of concentrations in $\mathrm{Cl}$, from 31 to $929 \mathrm{mmol} /$ $\mathrm{kg}$ (Table 2), in comparison to the ambient seawater value of $546.7 \mathrm{mmol} / \mathrm{kg}$. A classification of the fluids by their chlorinity shows the presence of an excellent correlation between total dissolved $\mathrm{Cl}$ and $\mathrm{Ca}-\mathrm{Na}-\mathrm{K}-(\mathrm{Mg})$ concentrations in the fluids. This suggests that secondary processes of phase separation have affected the cation composition of those hydrothermal fluids, an observation reinforced by the more pronounced dispersion of the cation concentrations above $300^{\circ} \mathrm{C}$, where these processes are more likely to occur [131].

A number of natural fluids show an apparent enrichment/depletion in $\mathrm{Mg}-\mathrm{Ca}-\mathrm{Na}-\mathrm{K}$ associated to an enrichment/depletion in chlorinity $(\mathrm{Cl}>567 \mathrm{mmol} / \mathrm{kg}$ and $<527 \mathrm{mmol} / \mathrm{kg}$, respectively). The model of this study therefore presents some limitations that hamper any further interpretation for these specific fluids subject to fluid phase separation processes. However, a limited number of natural fluids have conserved their original seawater chlorinity $\left(\mathrm{Cl}_{\mathrm{Sw}, 2^{\circ} \mathrm{C}}=546.7 \mathrm{mmol} / \mathrm{kg} \pm 20 \mathrm{mmol} / \mathrm{kg}\right)$ at temperatures up to $\sim 370^{\circ} \mathrm{C}$ (Figure 5), suggesting that they have not experienced phase separation processes during their ascent. At temperatures $>250^{\circ} \mathrm{C}$, the cation concentrations of these fluids deviate systematically from the original seawater concentration. Chlorine was documented to maintain a conservative behavior in hydrothermal fluids up to temperatures of $\sim 400^{\circ} \mathrm{C}$, at which point the precipitation and dissolution of chloride-bearing minerals begin [132]. We therefore interpret that the deviations observed for dissolved $\mathrm{Mg}-\mathrm{Ca}-\mathrm{Na}-\mathrm{K}$ concentrations at temperatures $>250^{\circ} \mathrm{C}$ and at conserved fluid chlorinity result from fluid/rock interaction processes that can be predicted using the model. The concentrations of these four elements show systematic deviations towards 
high temperatures, where $\mathrm{Mg}$ and $\mathrm{Na}$ are depleted while $\mathrm{Ca}$ and $\mathrm{K}$ are enriched in the fluid (dashed red arrows; Figure 5). In all cases, the cation concentrations tend towards the rock-buffered conditions predicted by the model. This evolution of the fluid composition towards rock-buffered conditions at high temperature is in agreement with the more limited circulation of seawater (i.e., low porosity and permeability) near the cracking front of the subaxial magma chamber, as documented by petrographic studies [9].

The systematic compositional evolution of submarine hydrothermal fluids towards low $\mathrm{F} / \mathrm{R}$ ratios at high temperature can be synthesized in a four-cation diagram (Figure 6) using ionic pairs typified by opposite behaviors in the fluid (i.e., $\mathrm{Mg}-\mathrm{Ca}$ and $\mathrm{K}-\mathrm{Na}$ ), as previously proposed by Giggenbach [133]. The diagram shows the predicted changes of seawater compositions associated to fluid/rock equilibria with basaltic rocks from seawater-buffered conditions towards the deepest and rock-buffered parts of the reaction zone. Instead of pointing at the composition corresponding to dissolved mid-ocean ridge basalts, the rock-buffered fluid end-member compositions are characterized by $\mathrm{Mg}-\mathrm{Na}$ depletions and $\mathrm{Ca}-\mathrm{K}$ enrichment characteristic of the overall fluid/rock interaction process predicted by the model (Figure 6). At the highest observed vent temperatures of $\sim 400^{\circ} \mathrm{C}$, fluid/rock interaction processes occurring at an $\mathrm{F} / \mathrm{R} \approx 1$ are interpreted to constitute the end-member composition of submarine hydrothermal fluids in mid-ocean ridge systems.

\section{Conclusions}

Hydrothermal processes at mid-ocean ridges are characterized by the equilibration of seawater with mafic rocks at temperatures up to $400^{\circ} \mathrm{C}$, leading to high temperature fluids of distinct compositions and the conversion of the fresh rocks into secondary mineral assemblages.

The existence of similar cation to proton activity ratios between the natural Icelandic waters and the simulations indicates that the model is able to closely reproduce the chemistry of fluid/rock interaction processes occurring in natural open systems. Although the Icelandic geothermal environment and submarine hydrothermal environment differ in fluid composition and rock permeability, the similar ionic exchange patterns occurring during fluid/rock interaction can be used to delineate the fundamental controls on the chemistry of natural fluids at mid-ocean ridges. Along with temperature, the $\mathrm{F} / \mathrm{R}$ ratio prevailing during seawaterbasalt interaction has a fundamental control on the resulting fluid chemistry. Rock-buffered conditions occur towards low $\mathrm{F} / \mathrm{R}$ ratios and are characterized by relatively high $a \mathrm{Ca}^{2+} /$ $\left(a \mathrm{H}^{+}\right)^{2}$ and $a \mathrm{Na}^{+} / a \mathrm{H}^{+}$values. A complex secondary mineral assemblage forms at these conditions, with numerous $\mathrm{Ca}$ and $\mathrm{Na}$-bearing phases, and the relatively alkaline nature of the solution is balanced by the nearly entire precipitation of $\mathrm{Mg}$. Hydrothermal alteration taking place under rockbuffered conditions is dominated by fresh basalt constituents and the effect of seawater is largely catalytic $[85,86]$. Seawater-buffered conditions occur towards high $\mathrm{F} / \mathrm{R}$ ratios

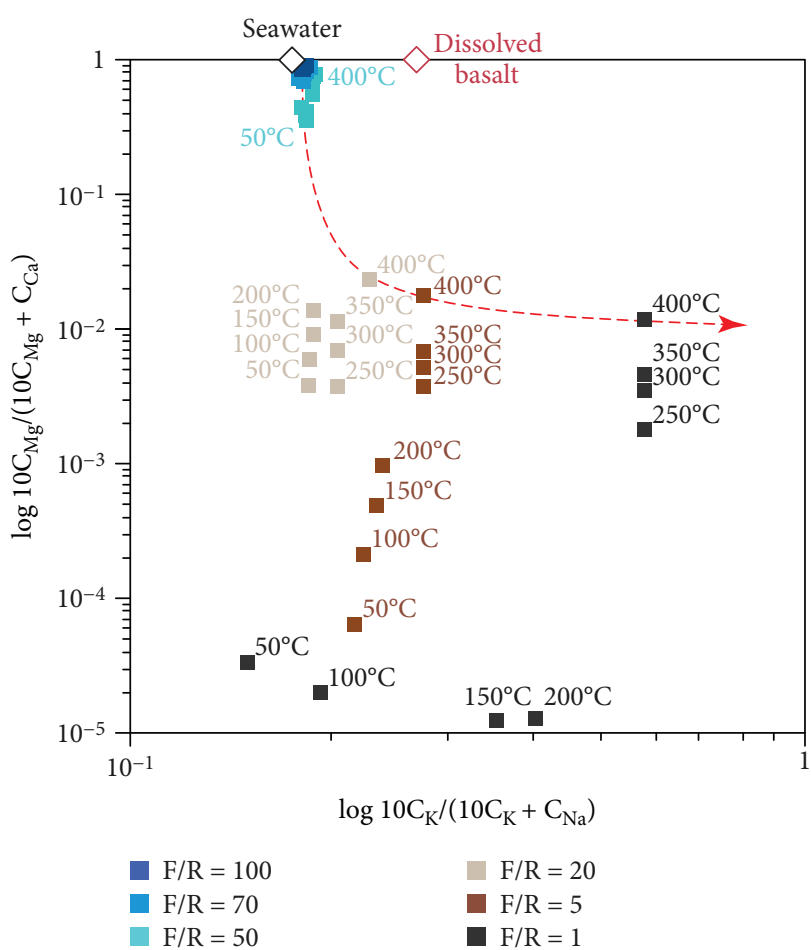

Figure 6: Plot of $10 \mathrm{C}_{\mathrm{K}} /\left(10 \mathrm{C}_{\mathrm{K}}+\mathrm{C}_{\mathrm{Na}}\right)$ versus log $10 \mathrm{C}_{\mathrm{Mg}} /\left(10 \mathrm{C}_{\mathrm{Mg}}+\right.$ $\mathrm{C}_{\mathrm{Ca}}$ ) with $\mathrm{Ci}$ in $\mathrm{mmol} / \mathrm{kg}$, representing the simulated compositional evolution of seawater reacting with basaltic rocks at equilibrium for variable fluid/rock $(\mathrm{F} / \mathrm{R})$ mass ratios, temperatures of 50 to $400^{\circ} \mathrm{C}$, and at a pressure of 500 bars. Black diamond represents the composition of seawater at $2^{\circ} \mathrm{C}$ and red diamond represents the isochemical dissolution of mid-ocean ridge basalt. The dashed red curve shows the evolution of the fluid composition from fluid-buffered to rock-buffered conditions at a temperature of $400^{\circ} \mathrm{C}$.

and generate relatively high $a \mathrm{Mg}^{2+} /\left(a \mathrm{H}^{+}\right)^{2}$ and low $\mathrm{pH}$ values. At these conditions, hydrothermal alteration is more influenced by seawater components than by the rock components. The mineral assemblage formed in seawaterdominated conditions consists of simple $\mathrm{Al}-\mathrm{Si}$ - and $\mathrm{Mg}$ bearing phases and a relatively acidic solution characterized by low $\mathrm{Ca}$ concentrations while $\mathrm{Mg}$ approaches the initial value of ambient seawater.

The excellent agreement obtained between the model and the compositions of a compilation of natural vent fluids from mid-ocean ridges suggests that fluid/rock interaction processes in the oceanic crust control both the chemistry of the fluids and the composition of the subseafloor alteration minerals. The vent chemistry is controlled by fluid/rock interaction processes during seawater circulation through the oceanic crust as well as by the subsequent processes of phase separation, as indicated by a wide range of fluid chlorinity. Only a small number of natural vent fluids have preserved their original fluid/rock interaction compositions without undergoing subsequent fluid phase separation. The study of these selected data reveals that at a nearmaximum temperature of $\sim 400^{\circ} \mathrm{C}$, the fluid composition is controlled by rock-buffered compositions marked by systematic Mg-Na depletions and $\mathrm{Ca}-\mathrm{K}$ enrichments. This 
compositional evolution of the fluid towards rock-buffered conditions at high temperature confirms the more limited circulation of seawater near the cracking front of the subaxial magma chamber previously indicated by petrographic studies [9]. At the highest observed vent temperatures of $\sim 400^{\circ} \mathrm{C}$, fluid/rock interaction processes occurring at an $\mathrm{F} / \mathrm{R} \approx 1$ are interpreted to constitute the end-member composition of submarine hydrothermal fluids in mid-ocean ridge systems. This study provides a verifiable model for the compositional evolution of submarine hydrothermal fluids at mid-ocean ridge and analogous basalt-dominated environments and constitutes a fundamental framework for future research on the controls on mass transfer associated with submarine hydrothermal systems.

\section{Data Availability}

The data used to support the findings of this study are included within the article. Thermodynamic data used for the minerals and aqueous species are archived as part of the MINES 17 database available at http://tdb.mines.edu.

\section{Conflicts of Interest}

The authors declare that there are no conflicts of interest regarding the publication of this paper.

\section{References}

[1] M. R. Perfit and J. P. Davidson, "Plate tectonics and volcanism," in Encyclopedia of Volcanoes, pp. 89-113, Academic Press, 2000.

[2] M. J. Mottl, "Partitioning of energy and mass fluxes between mid-ocean ridge axes and flanks at high and low temperature," in Energy and Mass Transfer in Marine Hydrothermal Systems, vol. 89, pp. 271-286, Dahlem University Press, 2003.

[3] J. B. Corliss, J. Dymond, L. I. Gordon et al., "Submarine thermal springs on the Galápagos Rift," Science, vol. 203, no. 4385, pp. 1073-1083, 1979.

[4] J. Francheteau, H. D. Needham, P. Choukroune et al., "Massive deep-sea sulphide ore deposits discovered on the East Pacific Rise," Nature, vol. 277, no. 5697, pp. 523-528, 1979.

[5] J. L. Bischoff and W. E. Seyfried, "Hydrothermal chemistry of seawater from $25^{\circ}$ to $350^{\circ} \mathrm{C}$," American Journal of Science, vol. 278, no. 6, pp. 838-860, 1978.

[6] T. Jupp and A. Schultz, "A thermodynamic explanation for black smoker temperatures," Nature, vol. 403, no. 6772, pp. 880-883, 2000.

[7] J. L. Bischoff and F. W. Dickson, "Seawater-basalt interaction at $200^{\circ} \mathrm{C}$ and 500 bars: implications for origin of sea-floor heavy-metal deposits and regulation of seawater chemistry," Earth and Planetary Science Letters, vol. 25, no. 3, pp. 385397, 1975.

[8] M. J. Mottl and H. D. Holland, "Chemical exchange during hydrothermal alteration of basalt by seawater-I. Experimental results for major and minor components of seawater," Geochimica et Cosmochimica Acta, vol. 42, no. 8, pp. 1103$1115,1978$.
[9] J. C. Alt, "Subseafloor processes in mid-ocean ridge hydrothermal systems," Geophysical Monograph, vol. 91, pp. 85-114, 1995.

[10] D. Coumou, T. Driesner, P. Weis, and C. A. Heinrich, "Phase separation, brine formation, and salinity variation at black smoker hydrothermal systems," Journal of Geophysical Research: Solid Earth, vol. 114, no. B3, article B03212, 2009.

[11] M. J. Mottl and W. E. Seyfried, "Sub-seafloor hydrothermal systems: rock- vs. seawater-dominated," in Seafloor Spreading Centers: Hydrothermal Systems, P. A. Rona and R. P. Lowell, Eds., pp. 66-82, Hutchinson \& Ross, Inc., 1980.

[12] M. H. Reed, "Seawater-basalt reaction and the origin of greenstones and related ore deposits," Economic Geology, vol. 78, no. 3, pp. 466-485, 1983.

[13] T. S. Bowers and H. P. Taylor Jr., "An integrated chemical and stable-isotope model of the origin of midocean ridge hot spring systems," Journal of Geophysical Research, vol. 90, no. B14, pp. 12583-12606, 1985.

[14] M. E. Berndt, W. E. Seyfried Jr., and D. R. Janecky, "Plagioclase and epidote buffering of cation ratios in mid-ocean ridge hydrothermal fluids: experimental results in and near the supercritical region," Geochimica et Cosmochimica Acta, vol. 53, no. 9, pp. 2283-2300, 1989.

[15] W. E. Seyfried Jr., K. Ding, and M. E. Berndt, "Phase equilibria constraints on the chemistry of hot spring fluids at mid-ocean ridges," Geochimica et Cosmochimica Acta, vol. 55, no. 12, pp. 3559-3580, 1991.

[16] L. R. Wetzel and E. L. Shock, "Distinguishing ultramaficfrom basalt-hosted submarine hydrothermal systems by comparing calculated vent fluid compositions," Journal of Geophysical Research, vol. 105, no. B4, pp. 8319-8340, 2000.

[17] T. S. Bowers, A. C. Campbell, C. I. Measures, A. J. Spivack, M. Khadem, and J. M. Edmond, "Chemical controls on the composition of vent fluids at $13^{\circ}-11^{\circ} \mathrm{N}$ and $21^{\circ} \mathrm{N}$, East Pacific Rise," Journal of Geophysical Research, vol. 93, no. B5, pp. 4522-4536, 1988.

[18] W. C. Shanks, "Stable isotopes in seafloor hydrothermal systems: vent fluids, hydrothermal deposits, hydrothermal alteration, and microbial processes," Reviews in Mineralogy and Geochemistry, vol. 43, no. 1, pp. 469-525, 2001.

[19] K. L. Von Damm, M. D. Lilley, W. C. Shanks III et al., "Extraordinary phase separation and segregation in vent fluids from the southern East Pacific Rise," Earth and Planetary Science Letters, vol. 206, no. 3-4, pp. 365-378, 2003.

[20] R. H. James, D. R. H. Green, M. J. Stock et al., "Composition of hydrothermal fluids and mineralogy of associated chimney material on the East Scotia Ridge back-arc spreading centre," Geochimica et Cosmochimica Acta, vol. 139, pp. 47-71, 2014.

[21] T. J. Wolery and N. H. Sleep, "Hydrothermal circulation and geochemical flux at mid-ocean ridges," Journal of Geology, vol. 84, no. 3, pp. 249-275, 1976.

[22] A. J. Spivack and J. M. Edmond, "Boron isotope exchange between seawater and the oceanic crust," Geochimica et Cosmochimica Acta, vol. 51, no. 5, pp. 1033-1043, 1987.

[23] K. L. Von Damm, "Controls on the chemistry and temporal variability of seafloor hydrothermal fluids," in Seafloor Hydrothermal Systems: Physical, Chemical, Biological, and Geological Interactions, S. E. Humphris, R. A. Zierenberg, L. S. Mullineaux, and R. E. Thomson, Eds., pp. 222-247, American Geophysical Union, Washington, DC, USA, 1995. 
[24] I. Y. Melekestseva, V. V. Maslennikov, G. A. Tret'yakov et al., "Gold- and silver-rich massive sulfides from the Semenov-2 hydrothermal field, $13^{\circ} 31.13^{\prime} \mathrm{N}$, Mid-Atlantic Ridge: a case of magmatic contribution?," Economic Geology, vol. 112, no. 4, pp. 741-773, 2017.

[25] I. K. Karpov, K. V. Chudnenko, and D. A. Kulik, "Modeling chemical mass transfer in geochemical processes: thermodynamic relations, conditions of equilibria, and numerical algorithms," American Journal of Science, vol. 297, no. 8, pp. 767-806, 1997.

[26] I. K. Karpov, K. V. Chudnenko, D. A. Kulik, O. V. Avchenko, and V. A. Bychinskii, "Minimization of Gibbs free energy in geochemical systems by convex programming," Geochemistry International, vol. 39, no. 11, pp. 1108-1119, 2001.

[27] D. A. Kulik, "Dual-thermodynamic estimation of stoichiometry and stability of solid solution end members in aqueoussolid solution systems," Chemical Geology, vol. 225, no. 3-4, pp. 189-212, 2006.

[28] D. A. Kulik, T. Wagner, S. V. Dmytrieva et al., "GEMSelektor geochemical modeling package: revised algorithm and GEMS3K numerical kernel for coupled simulation codes," Computational Geosciences, vol. 17, no. 1, pp. 1-24, 2013.

[29] A. P. Gysi, "Numerical simulations of $\mathrm{CO}_{2}$ sequestration in basaltic rock formations: challenges for optimizing mineralfluid reactions," Pure and Applied Chemistry, vol. 89, no. 5, pp. 581-596, 2017.

[30] T. J. B. Holland and R. Powell, "An internally consistent thermodynamic data set for phases of petrological interest," Journal of Metamorphic Geology, vol. 16, no. 3, pp. 309-343, 1998.

[31] A. P. Gysi and A. Stefánsson, " $\mathrm{CO}_{2}$-water-basalt interaction. Numerical simulation of low temperature $\mathrm{CO}_{2}$ sequestration into basalts," Geochimica et Cosmochimica Acta, vol. 75, no. 17, pp. 4728-4751, 2011.

[32] E. L. Shock and H. C. Helgeson, "Calculation of the thermodynamic and transport properties of aqueous species at high pressures and temperatures: correlation algorithms for ionic species and equation of state predictions to $5 \mathrm{~kb}$ and $1000^{\circ}$ C," Geochimica et Cosmochimica Acta, vol. 52, no. 8, pp. 2009-2036, 1988.

[33] J. W. Johnson, E. H. Oelkers, and H. C. Helgeson, "SUPCRT92: a software package for calculating the standard molal thermodynamic properties of minerals, gases, aqueous species, and reactions from 1 to 5000 bar and 0 to $1000^{\circ} \mathrm{C}$," Computers \& Geosciences, vol. 18, no. 7, pp. 899-947, 1992.

[34] E. L. Shock, D. C. Sassani, M. Willis, and D. A. Sverjensky, "Inorganic species in geologic fluids: correlations among standard molal thermodynamic properties of aqueous ions and hydroxide complexes," Geochimica et Cosmochimica Acta, vol. 61, no. 5, pp. 907-950, 1997.

[35] B. R. Tagirov, A. V. Zotov, and N. N. Akinfiev, "Experimental study of dissociation of $\mathrm{HCl}$ from 350 to $500^{\circ} \mathrm{C}$ and from 500 to 2500 bars: thermodynamic properties of $\mathrm{HCl}^{\circ}{ }_{(\mathrm{aq})}$," Geochimica et Cosmochimica Acta, vol. 61, no. 20, pp. 4267-4280, 1997.

[36] G. D. Miron, T. Wagner, D. A. Kulik, and C. A. Heinrich, "Internally consistent thermodynamic data for aqueous species in the system Na-K-Al-Si-O-H-Cl," Geochimica et Cosmochimica Acta, vol. 187, pp. 41-78, 2016.

[37] G. D. Miron, D. A. Kulik, S. V. Dmytrieva, and T. Wagner, "GEMSFITS: code package for optimization of geochemical model parameters and inverse modeling," Applied Geochemistry, vol. 55, pp. 28-45, 2015.

[38] G. D. Miron, T. Wagner, D. A. Kulik, and B. Lothenbach, “An internally consistent thermodynamic dataset for aqueous species in the system Ca-Mg-Na-K-Al-Si-O-H-C-Cl to $800^{\circ} \mathrm{C}$ and 5 kbar," American Journal of Science, vol. 317, no. 7, pp. 755-806, 2017.

[39] R. G. Arnold, R. G. Coleman, and V. C. Fryklund, “Temperature of crystallization of pyrrhotite and sphalerite from the Highland-Surprise Mine, Coeur d'Alene district, Idaho," Economic Geology, vol. 57, no. 8, pp. 1163-1174, 1962.

[40] P. F. Lonsdale, J. L. Bischoff, V. M. Burns, M. Kastner, and R. E. Sweeney, "A high-temperature hydrothermal deposit on the seabed at a Gulf of California Spreading Center," Earth and Planetary Science Letters, vol. 49, no. 1, pp. 8-20, 1980.

[41] R. W. Henley and A. J. Ellis, "Geothermal systems ancient and modern: a geochemical review," Earth-Science Reviews, vol. 19, no. 1, pp. 1-50, 1983

[42] D. M. Jenkins, R. C. Newton, and J. R. Goldsmith, "Relative stability of Fe-free zoisite and clinozoisite," Journal of Geology, vol. 93, no. 6, pp. 663-672, 1985.

[43] A. G. Reyes, "Petrology of Philippine geothermal systems and the application of alteration mineralogy to their assessment," Journal of Volcanology and Geothermal Research, vol. 43, no. 1-4, pp. 279-309, 1990.

[44] M. D. Hannington, I. R. Jonasson, P. M. Herzig, and S. Petersen, "Physical and chemical processes of seafloor mineralization at mid-ocean ridges," in Seafloor Hydrothermal Systems: Physical, Chemical, Biological, and Geological Interactions, S. E. Humphris, R. A. Zierenberg, L. S. Mullineaux, and R. E. Thomson, Eds., pp. 115-157, American Geophysical Union, Washington, DC, USA, 1995.

[45] N. C. White and J. W. Hedenquist, "Epithermal gold deposits: styles, characteristics and exploration," SEG Newsletter, vol. 23, no. 1, pp. 9-13, 1995.

[46] C. Jové and B. R. Hacker, "Experimental investigation of laumontite $\rightarrow$ wairakite $+\mathrm{H}_{2} \mathrm{O}:$ a model diagenetic reaction," American Mineralogist, vol. 82, no. 7-8, pp. 781-789, 1997.

[47] S. J. Chipera and J. A. Apps, "Geochemical stability of natural zeolites," Reviews in Mineralogy and Geochemistry, vol. 45, no. 1, pp. 117-161, 2001.

[48] D. K. Bird and A. R. Spieler, "Epidote in geothermal systems," Reviews in Mineralogy and Geochemistry, vol. 56, no. 1, pp. 235-300, 2004.

[49] T. Monecke, G. Giorgetti, O. Scholtysek et al., "Textural and mineralogical changes associated with the incipient hydrothermal alteration of glassy dacite at the submarine PACMANUS hydrothermal system, eastern Manus Basin," Journal of Volcanology and Geothermal Research, vol. 160, no. 1-2, pp. 23-41, 2007.

[50] M. R. S. Hodgkinson, A. P. Webber, S. Roberts, R. A. Mills, D. P. Connelly, and B. J. Murton, "Talc-dominated seafloor deposits reveal a new class of hydrothermal system," Nature Communications, vol. 6, no. 1, article 10150, 2015.

[51] B. M. J. Thien, G. Kosakowski, and D. A. Kulik, "Differential alteration of basaltic lava flows and hyaloclastites in Icelandic hydrothermal systems," Geothermal Energy, vol. 3, no. 1, 2015.

[52] H. C. Helgeson, D. H. Kirkham, and G. C. Flowers, "Theoretical prediction of the thermodynamic behavior of aqueous electrolytes at high pressures and temperatures: IV. 
Calculation of activity coefficients, osmotic coefficients, and apparent molal and standard and relative partial molal properties to $600^{\circ} \mathrm{C}$ and $5 \mathrm{~kb}$," American Journal of Science, vol. 281, no. 10, pp. 1249-1516, 1981.

[53] D. A. Sverjensky, E. L. Shock, and H. C. Helgeson, "Prediction of the thermodynamic properties of aqueous metal complexes to $1000^{\circ} \mathrm{C}$ and $5 \mathrm{~kb}$," Geochimica et Cosmochimica Acta, vol. 61, no. 7, pp. 1359-1412, 1997.

[54] T. Wagner, D. A. Kulik, F. F. Hingerl, and S. V. Dmytrieva, "GEM-Selektor geochemical modeling package: TSolMod library and data interface for multicomponent phase models," Canadian Mineralogist, vol. 50, no. 5, pp. 11731195, 2012.

[55] K. A. Kelley and E. Cottrell, "Water and the oxidation state of subduction zone magmas," Science, vol. 325, no. 5940, pp. 605-607, 2009.

[56] F. J. Millero, R. Feistel, D. G. Wright, and T. J. McDougall, "The composition of standard seawater and the definition of the reference-composition salinity scale," Deep Sea Research Part I: Oceanographic Research Papers, vol. 55, no. 1, pp. 50-72, 2008.

[57] A. Koschinsky, D. Garbe-Schönberg, S. Sander, K. Schmidt, H.-H. Gennerich, and H. Strauss, "Hydrothermal venting at pressure-temperature conditions above the critical point of seawater, $5^{\circ} \mathrm{S}$ on the Mid-Atlantic Ridge," Geology, vol. 36, no. 8, pp. 615-618, 2008.

[58] M. D. Hannington, C. E. J. de Ronde, and S. Petersen, "Seafloor tectonics and submarine hydrothermal systems," in Economic Geology 100th Anniversary Volume, pp. 111-141, Society of Economic Geologists, Littelton, CO, USA, 2005.

[59] M. R. Perfit, W. I. Ridley, and I. R. Jonasson, "Geologic, petrologic, and geochemical relationships between magmatism and massive sulfide mineralization along the eastern Galapagos Spreading Center," Reviews in Economic Geology, vol. 8, pp. 75-100, 1999.

[60] F. J. Fontaine, W. S. D. Wilcock, D. E. Foustoukos, and D. A. Butterfield, "A Si-Cl geothermobarometer for the reaction zone of high-temperature, basaltic-hosted midocean ridge hydrothermal systems," Geochemistry, Geophysics, Geosystems, vol. 10, no. 5, 2009.

[61] H. C. Helgeson, "Evaluation of irreversible reactions in geochemical processes involving minerals and aqueous solutions-I. Thermodynamic relations," Geochimica et Cosmochimica Acta, vol. 32, no. 8, pp. 853-877, 1968.

[62] H. C. Helgeson, R. M. Garrels, and F. T. MacKenzie, "Evaluation of irreversible reactions in geochemical processes involving minerals and aqueous solutions-II. Applications," Geochimica et Cosmochimica Acta, vol. 33, no. 4, pp. 455481, 1969.

[63] A. Stefánsson, S. R. Gíslason, and S. Arnórsson, "Dissolution of primary minerals in natural waters II. Mineral saturation state," Chemical Geology, vol. 172, no. 3-4, pp. 251-276, 2001.

[64] S. Arnórsson and A. Stefánsson, "Assessment of feldspar solubility constants in water in the range of $0^{\circ}$ to $350^{\circ} \mathrm{C}$ at vapor saturation pressures," American Journal of Science, vol. 299, no. 3, pp. 173-209, 1999.

[65] D. Robinson and A. Santana De Zamora, "The smectite to chlorite transition in the Chipilapa geothermal system, El Salvador," American Mineralogist, vol. 84, no. 4, pp. 607619, 1999.
[66] D. R. Janecky and W. E. Seyfried, "The solubility of magnesium-hydroxide-sulfate-hydrate in seawater at elevated temperatures and pressures," American Journal of Science, vol. 283, no. 8, pp. 831-860, 1983.

[67] R. S. White, D. McKenzie, and R. K. O'Nions, "Oceanic crustal thickness from seismic measurements and rare earth element inversions," Journal of Geophysical Research, vol. 97, no. B13, pp. 19683-19715, 1992.

[68] S. R. Gíslason and E. H. Oelkers, "Mechanism, rates, and consequences of basaltic glass dissolution: II. An experimental study of the dissolution rates of basaltic glass as a function of $\mathrm{pH}$ and temperature," Geochimica et Cosmochimica Acta, vol. 67, no. 20, pp. 3817-3832, 2003.

[69] D. Wolff-Boenisch, S. R. Gíslason, and E. H. Oelkers, "The effect of crystallinity on dissolution rates and $\mathrm{CO}_{2}$ consumption capacity of silicates," Geochimica et Cosmochimica Acta, vol. 70, no. 4, pp. 858-870, 2006.

[70] S. Gudbrandsson, D. Wolff-Boenisch, S. R. Gíslason, and E. H. Oelkers, "An experimental study of crystalline basalt dissolution from $2 \leq \mathrm{pH} \leq 11$ and temperatures from 5 to $75^{\circ} \mathrm{C}$," Geochimica et Cosmochimica Acta, vol. 75, no. 19, pp. 5496-5509, 2011

[71] A. P. Gysi and A. Stefánsson, "Experiments and geochemical modeling of $\mathrm{CO}_{2}$ sequestration during hydrothermal basalt alteration," Chemical Geology, vol. 306-307, pp. 10-28, 2012.

[72] T. Van Pham, P. Aagaard, and H. Hellevang, "On the potential for $\mathrm{CO}_{2}$ mineral storage in continental flood basalts PHREEQC batch- and 1D diffusion-reaction simulations," Geochemical Transactions, vol. 13, no. 1, p. 5, 2012.

[73] A. C. Lasaga and D. M. Rye, "Fluid flow and chemical reaction kinetics in metamorphic systems," American Journal of Science, vol. 293, no. 5, pp. 361-404, 1993.

[74] A. C. Lasaga, "Fundamental approaches in describing mineral dissolution and precipitation rates," Reviews in Mineralogy and Geochemistry, vol. 31, no. 1, pp. 23-86, 1995.

[75] J.-L. Devidal, J. Schott, and J.-L. Dandurand, “An experimental study of kaolinite dissolution and precipitation kinetics as a function of chemical affinity and solution composition at $150^{\circ} \mathrm{C}, 40$ bars, and $\mathrm{pH} 2,6.8$, and 7.8," Geochimica et Cosmochimica Acta, vol. 61, no. 24, pp. 5165-5186, 1997.

[76] E. H. Oelkers and S. R. Gíslason, "The mechanism, rates and consequences of basaltic glass dissolution: I. An experimental study of the dissolution rates of basaltic glass as a function of aqueous $\mathrm{Al}, \mathrm{Si}$ and oxalic acid concentration at $25^{\circ} \mathrm{C}$ and $\mathrm{pH}=3$ and 11," Geochimica et Cosmochimica Acta, vol. 65, no. 21, pp. 3671-3681, 2001.

[77] S. R. Gíslason and H. P. Eugster, "Meteoric water-basalt interactions. II: a field study in N.E. Iceland," Geochimica et Cosmochimica Acta, vol. 51, no. 10, pp. 2841-2855, 1987.

[78] W. E. Seyfried Jr. and M. J. Mottl, "Hydrothermal alteration of basalt by seawater under seawater-dominated conditions," Geochimica et Cosmochimica Acta, vol. 46, no. 6, pp. 9851002, 1982.

[79] J. L. Crovisier, J. H. Thomassin, T. Juteau, J. P. Eberhart, J. C. Touray, and P. Baillif, "Experimental seawater-basaltic glass interaction at $50^{\circ} \mathrm{C}$ : study of early developed phases by electron microscopy and X-ray photoelectron spectrometry," Geochimica et Cosmochimica Acta, vol. 47, no. 3, pp. 377387, 1983.

[80] G. Berger, J. Schott, and M. Loubet, "Fundamental processes controlling the first stage of alteration of a basalt glass by 
seawater: an experimental study between $200^{\circ}$ and $320^{\circ} \mathrm{C}$," Earth and Planetary Science Letters, vol. 84, no. 4, pp. 431445, 1987.

[81] G. H. Kacandes and D. E. Grandstaff, "Differences between geothermal and experimentally derived fluids: how well do hydrothermal experiments model the composition of geothermal reservoir fluids?," Geochimica et Cosmochimica Acta, vol. 53, no. 2, pp. 343-358, 1989.

[82] A. Stefánsson and S. R. Gíslason, "Chemical weathering of basalts, Southwest Iceland: effect of rock crystallinity and secondary minerals on chemical fluxes to the ocean," American Journal of Science, vol. 301, no. 6, pp. 513-556, 2001.

[83] J.-L. Crovisier, J. Honnorez, B. Fritz, and J.-C. Petit, "Dissolution of subglacial volcanic glasses from Iceland: laboratory study and modelling," Applied Geochemistry, vol. 7, Supplement 1, pp. 55-81, 1992.

[84] J.-L. Crovisier, T. Advocat, and J.-L. Dussossoy, "Nature and role of natural alteration gels formed on the surface of ancient volcanic glasses (natural analogs of waste containment glasses)," Journal of Nuclear Materials, vol. 321, no. 1, pp. 91-109, 2003.

[85] S. Arnórsson, E. Gunnlaugsson, and H. Svavarsson, "The chemistry of geothermal waters in Iceland. II. Mineral equilibria and independent variables controlling water compositions," Geochimica et Cosmochimica Acta, vol. 47, no. 3, pp. 547-566, 1983.

[86] W. F. Giggenbach, "Mass transfer in hydrothermal alteration systems-a conceptual approach," Geochimica et Cosmochimica Acta, vol. 48, no. 12, pp. 2693-2711, 1984.

[87] P. R. L. Browne, "Hydrothermal alteration in active geothermal fields," Annual Review of Earth and Planetary Sciences, vol. 6, no. 1, pp. 229-248, 1978.

[88] P. S. Neuhoff, T. Fridriksson, S. Arnórsson, and D. K. Bird, "Porosity evolution and mineral paragenesis during lowgrade metamorphism of basaltic lavas at Teigarhorn, eastern Iceland," American Journal of Science, vol. 299, no. 6, pp. 467-501, 1999.

[89] T. Weisenberger and R. S. Selbekk, "Multi-stage zeolite facies mineralization in the Hvalfjördur area, Iceland," International Journal of Earth Sciences, vol. 98, no. 5, pp. 985-999, 2009.

[90] P. S. Neuhoff, K. L. Rogers, L. S. Stannius, D. K. Bird, and A. K. Pedersen, "Regional very low-grade metamorphism of basaltic lavas, Disko-Nuussuaq region, West Greenland," Lithos, vol. 92, no. 1-2, pp. 33-54, 2006.

[91] A. Steiner, "Wairakite, the calcium analogue of analcime, a new zeolite mineral," Mineralogical Magazine, vol. 30, no. 230, pp. 691-698, 1955.

[92] M. Utada, "Zeolitization in the Neogene formations of Japan,” Episodes, vol. 14, no. 3, pp. 242-245, 1991.

[93] L. G. Viereck, B. J. Griffin, H.-U. Schmincke, and R. G. Pritchard, "Volcaniclastic rocks of the Reydarfjordur drill hole, eastern Iceland. 2. Alteration," Journal of Geophysical Research, vol. 87, no. B8, pp. 6459-6476, 1982.

[94] P. Schiffman and G. O. Fridleifsson, "The smectite-chlorite transition in drillhole NJ-15, Nesjavellir geothermal field, Iceland: XRD, BSE and electron microprobe investigations," Journal of Metamorphic Geology, vol. 9, no. 6, pp. 679-696, 1991.

[95] D. Robinson, S. T. Schmidt, and A. Santana De Zamora, "Reaction pathways and reaction progress for the smectite- to-chlorite transformation: evidence from hydrothermally altered metabasites," Journal of Metamorphic Geology, vol. 20, no. 1, pp. 167-174, 2002.

[96] H. A. Mínguez, L. Ortega, R. Lunar, J. M. Frías, and R. Piña, "Mineralogy of the hydrothermal alteration in the Námafjall geothermal field (Iceland)," Revista de la Sociedad Española de Mineralogia, vol. 15, pp. 25-26, 2011.

[97] G. L. Früh-Green, A. Plas, and C. Lécuyer, "Petrologic and stable isotope constraints on hydrothermal alteration and serpentinization of the EPR shallow mantle at Hess Deep (site 895)," Proceedings of the Ocean Drilling Program, Scientific Results, vol. 147, pp. 255-291, 1996.

[98] H. Furnes and M. I. H. El-Anbaawy, "Chemical changes and authigenic mineral formation during palagonitization of a basanite hyaloclastite, Gran Canaria, Canary Islands," Neues Jahrbuch für Mineralogie-Abhandlungen, vol. 139, pp. 279302, 1980 .

[99] W. F. Giggenbach, "Magma degassing and mineral deposition in hydrothermal systems along convergent plate boundaries," Economic Geology, vol. 87, pp. 1927-1944, 1992.

[100] M. Hannington, P. Herzig, P. Stoffers et al., "First observations of high-temperature submarine hydrothermal vents and massive anhydrite deposits off the north coast of Iceland," Marine Geology, vol. 177, no. 3-4, pp. 199-220, 2001.

[101] V. M. Dekov, J. Cuadros, W. C. Shanks, and R. A. Koski, "Deposition of talc-kerolite-smectite-smectite at seafloor hydrothermal vent fields: evidence from mineralogical, geochemical and oxygen isotope studies," Chemical Geology, vol. 247, no. 1-2, pp. 171-194, 2008.

[102] K. L. Rogers, P. S. Neuhoff, A. K. Pedersen, and D. K. Bird, " $\mathrm{CO}_{2}$ metasomatism in a basalt-hosted petroleum reservoir, Nuussuaq, West Greenland," Lithos, vol. 92, no. 1-2, pp. 55-82, 2006.

[103] C. Laverne, "Occurrence of siderite and ankerite in young basalts from the Galápagos Spreading Center (DSDP holes 506G and 507B)," Chemical Geology, vol. 106, no. 1-2, pp. 27-46, 1993.

[104] K. Nakamura and Y. Kato, "Carbonatization of oceanic crust by the seafloor hydrothermal activity and its significance as a $\mathrm{CO}_{2}$ sink in the early Archean," Geochimica et Cosmochimica Acta, vol. 68, no. 22, pp. 4595-4618, 2004.

[105] A. P. Gysi and A. Stefánsson, "Mineralogical aspects of $\mathrm{CO}_{2}$ sequestration during hydrothermal basalt alteration-an experimental study at 75 to $250^{\circ} \mathrm{C}$ and elevated $p \mathrm{CO}_{2}$," Chemical Geology, vol. 306-307, pp. 146-159, 2012.

[106] R. J. Rosenbauer, J. L. Bischoff, and R. A. Zierenberg, "The laboratory albitization of mid-ocean ridge basalt," Journal of Geology, vol. 96, no. 2, pp. 237-244, 1988.

[107] R. Shiraki and J. T. Iiyama, "Na-K ion exchange reaction between rhyolitic glass and $(\mathrm{Na}, \mathrm{K}) \mathrm{Cl}$ aqueous solution under hydrothermal conditions," Geochimica et Cosmochimica Acta, vol. 54, no. 11, pp. 2923-2931, 1990.

[108] A. Stefánsson and S. Arnórsson, "Feldspar saturation state in natural waters," Geochimica et Cosmochimica Acta, vol. 64, no. 15, pp. 2567-2584, 2000.

[109] R. N. Greenberger, J. F. Mustard, E. A. Cloutis et al., "Hydrothermal alteration and diagenesis of terrestrial lacustrine pillow basalts: coordination of hyperspectral imaging with laboratory measurements," Geochimica et Cosmochimica Acta, vol. 171, pp. 174-200, 2015. 
[110] J. G. Arnason, D. K. Bird, and J. G. Liou, "Variables controlling epidote composition in hydrothermal and low-pressure regional metamorphic rocks," Abhandlungen der Geologischen Bundesanstalt Wien, vol. 49, pp. 17-25, 1993.

[111] J. M. Mehegan, P. T. Robinson, and J. R. Delaney, "Secondary mineralization and hydrothermal alteration in the Reydarfjordur drill core, eastern Iceland," Journal of Geophysical Research, vol. 87, no. B8, pp. 6511-6524, 1982.

[112] M. J. Mottl, "Metabasalts, axial hot springs, and the structure of hydrothermal systems at mid-ocean ridges," Geological Society of America Bulletin, vol. 94, no. 2, pp. 161-180, 1983.

[113] W. C. Shanks III and W. E. Seyfried Jr., "Stable isotope studies of vent fluids and chimney minerals, southern Juan de Fuca Ridge: sodium metasomatism and seawater sulfate reduction," Journal of Geophysical Research, vol. 92, no. B11, pp. 11387-11399, 1987.

[114] M. Hannington, P. Herzig, S. Scott, G. Thompson, and P. Rona, "Comparative mineralogy and geochemistry of gold-bearing sulfide deposits on the mid-ocean ridges," Marine Geology, vol. 101, no. 1-4, pp. 217-248, 1991.

[115] W. F. Giggenbach, "Redox processes governing the chemistry of fumarolic gas discharges from White Island, New Zealand," Applied Geochemistry, vol. 2, no. 2, pp. 143-161, 1987.

[116] M. T. Einaudi, J. W. Hedenquist, and E. E. Inan, "Sulfidation state of fluids in active and extinct hydrothermal systems: transitions from porphyry to epithermal environments," Society of Economic Geologists Special Publication, vol. 10, pp. 285-313, 2003.

[117] A. Stefánsson, "Gas chemistry of Icelandic thermal fluids," Journal of Volcanology and Geothermal Research, vol. 346, pp. 81-94, 2017.

[118] R. M. Garrels, "Genesis of some ground waters from igneous rocks," Researches in Geochemistry, vol. 2, pp. 405-420, 1967.

[119] S. Arnórsson, E. Gunnlaugsson, and H. Svavarsson, “The chemistry of geothermal waters in Iceland. III. Chemical geothermometry in geothermal investigations," Geochimica et Cosmochimica Acta, vol. 47, no. 3, pp. 567-577, 1983.

[120] S. R. Gíslason and S. Arnórsson, "Dissolution of primary basaltic minerals in natural waters: saturation state and kinetics," Chemical Geology, vol. 105, no. 1-3, pp. 117-135, 1993.

[121] A. Hajash and G. W. Chandler, "An experimental investigation of high-temperature interactions between seawater and rhyolite, andesite, basalt and peridotite," Contributions to Mineralogy and Petrology, vol. 78, no. 3, pp. 240-254, 1982.

[122] J. C. Alt, "Sulfur isotopic profile through the oceanic crust: sulfur mobility and seawater-crustal sulfur exchange during hydrothermal alteration," Geology, vol. 23, no. 7, pp. 585588, 1995.

[123] D. S. Kelley, K. M. Gillis, and G. Thompson, "Fluid evolution in submarine magma-hydrothermal systems at the MidAtlantic Ridge," Journal of Geophysical Research, vol. 98, no. B11, pp. 19579-19596, 1993.

[124] R. M. Gallant and K. L. Von Damm, "Geochemical controls on hydrothermal fluids from the Kairei and Edmond vent fields, $23^{\circ}-25^{\circ}$ S, Central Indian Ridge," Geochemistry, Geophysics, Geosystems, vol. 7, no. 6, 2006.

[125] T. Gamo, H. Chiba, T. Yamanaka et al., "Chemical characteristics of newly discovered black smoker fluids and associated hydrothermal plumes at the Rodriguez Triple Junction, Central Indian Ridge," Earth and Planetary Science Letters, vol. 193, no. 3-4, pp. 371-379, 2001.
[126] K. L. Von Damm, "Chemistry of hydrothermal vent fluids from $9^{\circ}-10^{\circ} \mathrm{N}$, East Pacific Rise: "time zero," the immediate posteruptive period," Journal of Geophysical Research, vol. 105, no. B5, pp. 11203-11222, 2000.

[127] J. L. Charlou, Y. Fouquet, J. P. Donval et al., "Mineral and gas chemistry of hydrothermal fluids on an ultrafast spreading ridge: East Pacific Rise, $17^{\circ}$ to $19^{\circ} \mathrm{S}$ (Naudur cruise, 1993) phase separation processes controlled by volcanic and tectonic activity," Journal of Geophysical Research, vol. 101, no. B7, pp. 15899-15919, 1996.

[128] K. L. Von Damm, A. M. Bray, L. G. Buttermore, and S. E. Oosting, "The geochemical controls on vent fluids from the Lucky Strike vent field, Mid-Atlantic Ridge," Earth and Planetary Science Letters, vol. 160, no. 3-4, pp. 521-536, 1998.

[129] K. Schmidt, D. Garbe-Schönberg, M. D. Hannington et al., "Boiling vapour-type fluids from the Nifonea vent field (New Hebrides back-arc, Vanuatu, SW Pacific): geochemistry of an early-stage, post-eruptive hydrothermal system," Geochimica et Cosmochimica Acta, vol. 207, pp. 185-209, 2017.

[130] E. P. Reeves, J. S. Seewald, P. Saccocia et al., "Geochemistry of hydrothermal fluids from the PACMANUS, Northeast Pual and Vienna Woods hydrothermal fields, Manus Basin, Papua New Guinea," Geochimica et Cosmochimica Acta, vol. 75, no. 4, pp. 1088-1123, 2011.

[131] T. Monecke, S. Petersen, and M. D. Hannington, "Constraints on water depth of massive sulfide formation: evidence from modern seafloor hydrothermal systems in arc-related settings," Economic Geology, vol. 109, no. 8, pp. 2079-2101, 2014.

[132] M. E. Berndt and W. E. Seyfried Jr., "Boron, bromine, and other trace elements as clues to the fate of chlorine in midocean ridge vent fluids," Geochimica et Cosmochimica Acta, vol. 54, no. 8, pp. 2235-2245, 1990.

[133] W. F. Giggenbach, "Geothermal solute equilibria. Derivation of Na-K-Mg-Ca geoindicators," Geochimica et Cosmochimica Acta, vol. 52, no. 12, pp. 2749-2765, 1988. 

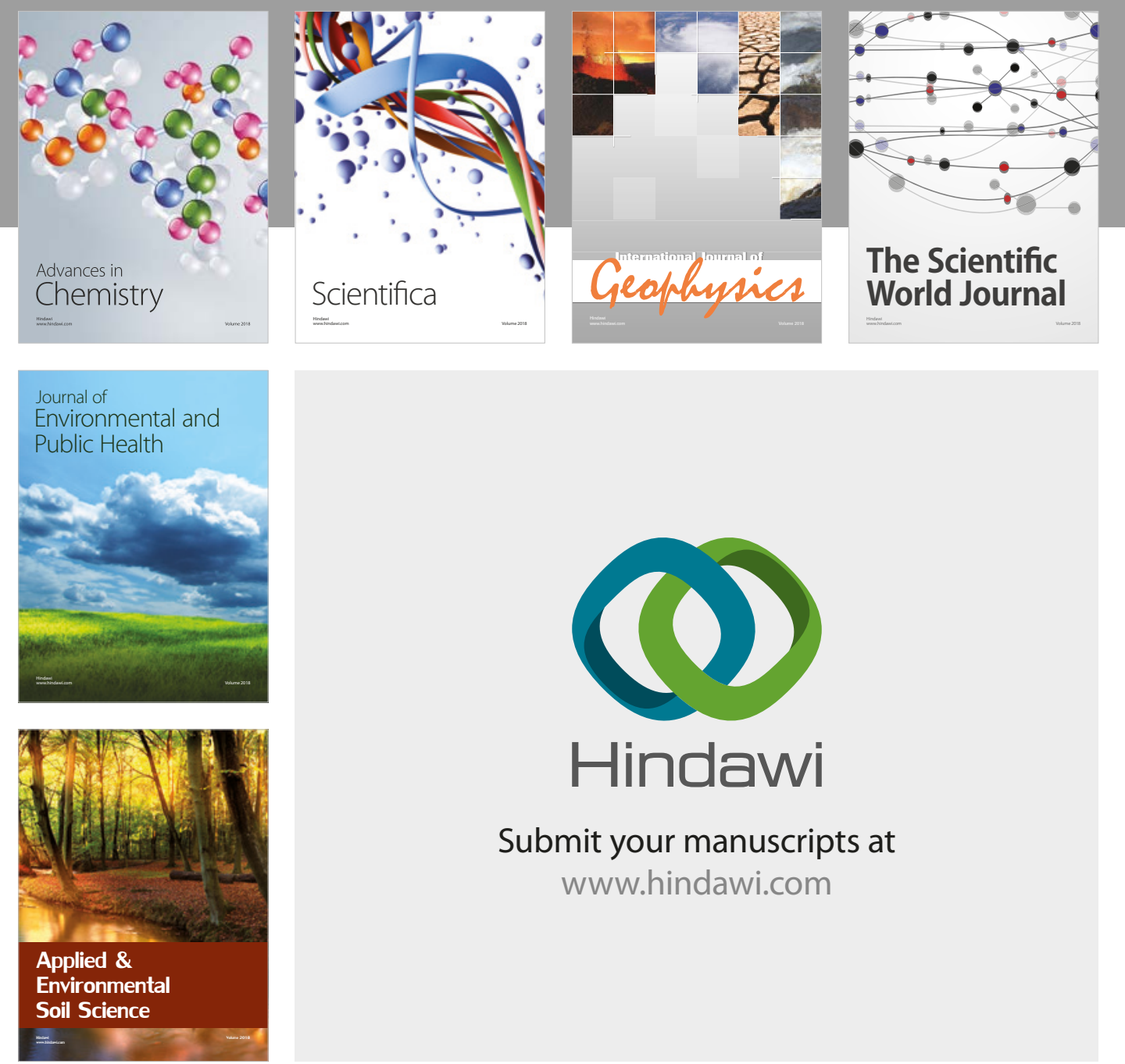

The Scientific

\section{World Journal}
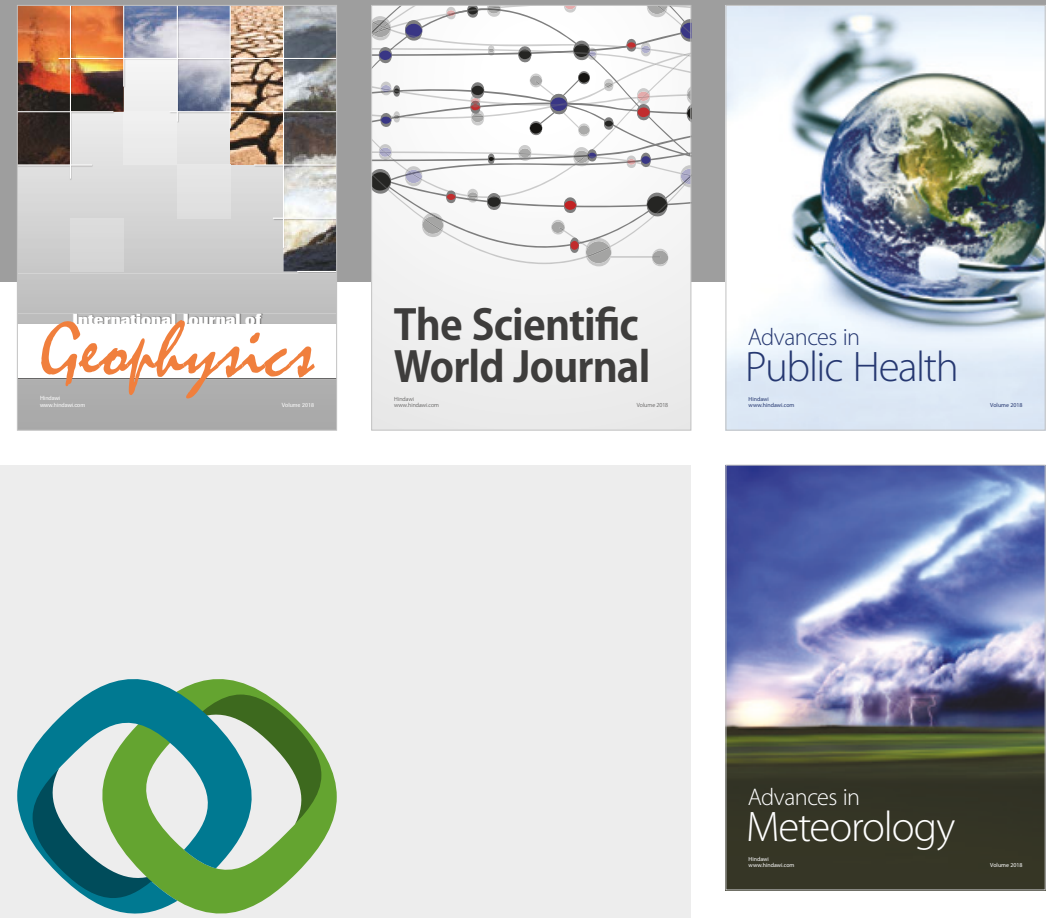

Advan

Public Health

\section{Hindawi}

Submit your manuscripts at

www.hindawi.com
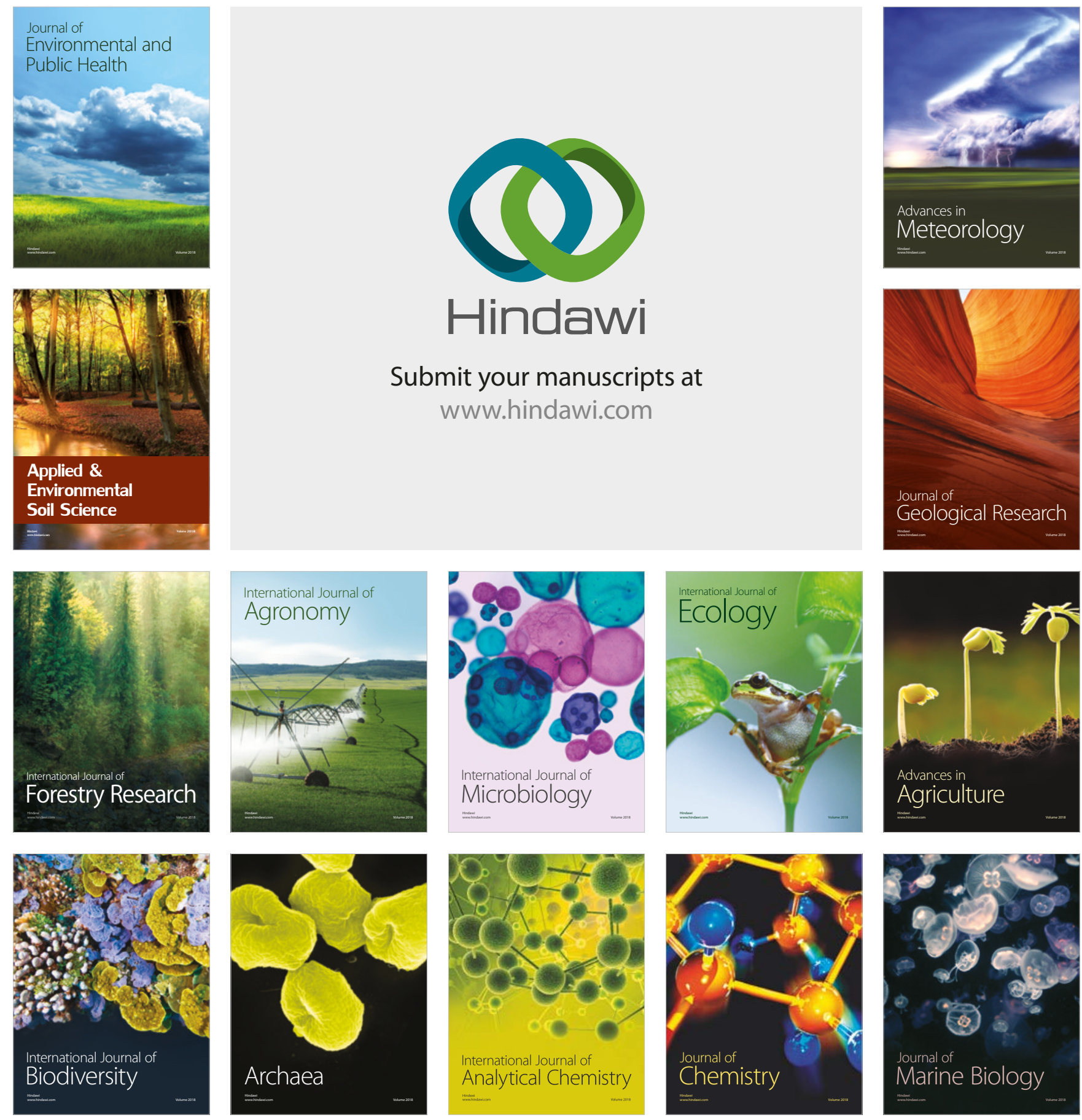